\title{
Didelphis spp. opossums and their parasites in the Americas: A One Health perspective
}

\author{
Marcos Antônio Bezerra-Santos ${ }^{1} \cdot$ Rafael Antonio Nascimento Ramos ${ }^{2} \cdot$ Artur Kanadani Campos $^{3}$. \\ Filipe Dantas-Torres ${ }^{4} \cdot$ Domenico Otranto $^{1,5}$
}

Received: 17 September 2020 / Accepted: 26 January 2021 / Published online: 31 March 2021

(C) The Author(s) 2021

\begin{abstract}
Medium sized opossums (Didelphis spp.) are among the most fascinating mammals of the Americas, playing important ecological roles (e.g., dispersal of seeds and control of insect populations) in the environment they inhabit. Nevertheless, as synanthropic animals, they are well adapted to human dwellings, occupying shelters within the cities, peripheral areas, and rural settings. These marsupials can harbor numerous pathogens, which may affect people, pets, and livestock. Among those, some protozoa (e.g., Leishmania infantum, Trypanosoma cruzi, Toxoplasma gondii), helminths (e.g., Ancylostoma caninum, Trichinella spiralis, Alaria marcianae, Paragonimus spp.) and arthropods (e.g., ticks, fleas) present substantial public health and veterinary importance, due to their capacity to cause disease in humans, domestic animals, and wildlife. Here, we reviewed the role played by opossums on the spreading of zoonotic parasites, vectors, and vector-borne pathogens, highlighting the risks of pathogens transmission due to the direct and indirect interaction of humans and domestic animals with Didelphis spp. in the Americas.
\end{abstract}

Keywords Didelphis spp. $\cdot$ Public health $\cdot$ Reservoirs $\cdot$ Vectors $\cdot$ Wildlife $\cdot$ Zoonotic parasites

\section{Introduction}

Over history, uncontrolled environmental changes promoted by humans have led to irreversible outcomes, affecting natural resources and consequently the biotic populations of the modified landscape (Acevedo-Whitehouse and Duffus 2009; Dantas-Torres 2015). For example, the impact of

Section Editor: Lihua Xiao

Domenico Otranto

domenico.otranto@uniba.it

1 Department of Veterinary Medicine, University of Bari, Valenzano, 70010 Bari, Italy

2 Laboratory of Parasitology, Federal University of the Agreste of Pernambuco, Garanhuns, Brazil

3 Department of Veterinary Medicine, Federal University of Viçosa, Viçosa, Brazil

4 Aggeu Magalhães Institute, Fundação Oswaldo Cruz (Fiocruz), Recife, Brazil

5 Department of Pathobiology, Faculty of Veterinary Science, Bu-Ali Sina University, Hamedan, Iran deforestation to give place to productive activities (e.g., livestock system and cropping) and construction of large cities has resulted in the extinction of wildlife species due to habitat loss and fragmentation of their populations (Rands et al. 2010; Pereira et al. 2010; Haddad et al. 2015). However, some species, such as medium sized opossums of the genus Didelphis (from this point will be referred in the text only as opossums), can adapt to human-modified landscapes due to their ability to exploit a wide range of resources and environments (CruzSalazar and Ruiz-Montoya 2020). The presence of such animals within human dwellings across the American continent brings important consequences (i.e., disease transmission) not only for humans and domestic animals, but also for themselves as they are victims of domestic animal attacks, roadkill (Fig. 1a) or directly killed by humans (Gumier-Costa and Sperber 2009; Rangel and Neiva 2013; Barros and Azevedo 2014).

Opossums' ability to thrive in different environments enabled them to become synanthropic species, benefiting from resources (e.g., food and shelter) available in human-modified areas (Olifiers et al. 2005; Jansen and Roque 2010). These marsupials are compatible hosts and suggested reservoirs of important parasites (e.g., Leishmania infantum and Trypanosoma cruzi) that cause human disease, and along with 


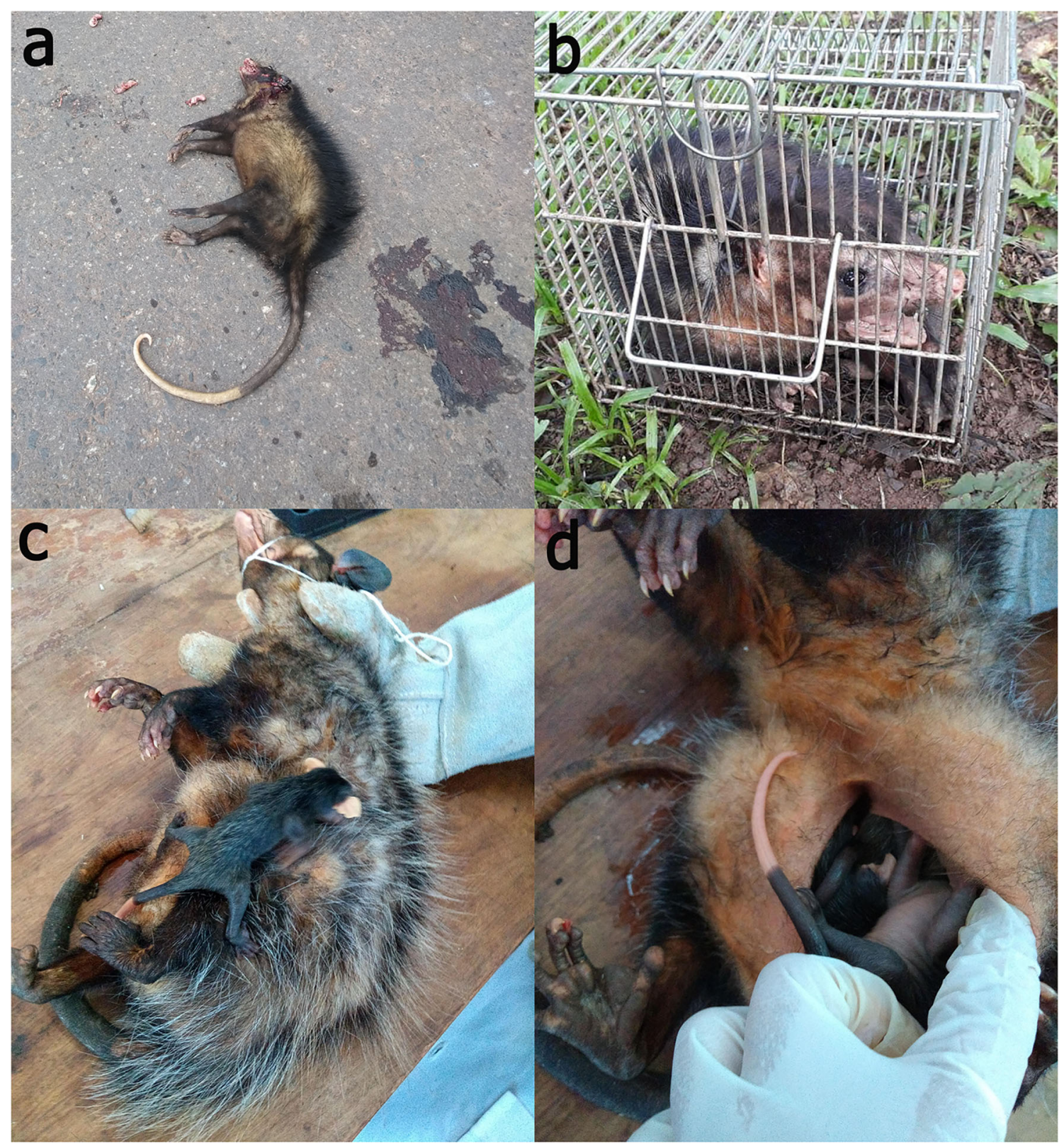

Fig. 1 a. Road killed Didelphis aurita female with its marsupium full of joeys; b. Didelphis aurita trapped through Tomahawk livetrap; c. Didelphis aurita female with joeys on its back; d. Didelphis aurita female with joeys inside the marsupium.

domestic animals, opossums are involved in the epidemiological cycle of such parasites within urban and periurban environments (Muller et al. 2005; Horta et al. 2010; Pena et al. 2011; Carreira et al. 2012). Additionally, opossums are also potential amplifiers of some pathogens, such as Rickettsia rickettsii (Horta et al. 2009).

Several pathogens present in wildlife are still unknown to science, and in many countries the illegal consumption of these animals exposes humans to infectious agents harbored by wildlife (Chomel et al. 2007; Júnior et al. 2010; BezerraSantos et al. 2021a, b). For example, opossums have been consumed by local communities as food or even as traditional medicine (e.g., opossum fat) in some regions of the Americas, which in many situations lead to local illegal trade of these animals (Júnior et al. 2010; Barros and Azevedo 2014; de Oliveira Carneiro et al. 2019). Such habits impose substantial health risks for people consuming or handling opossums' meat/carcasses, due to lack of monitoring of the health status of these animals, poor hygienic conditions when manipulating their meat (e.g., cross contamination due to the contact of the animals' feces, blood, saliva, urine with other food items such as raw vegetables) and inadequate cooking. Here, we reviewed the role played by opossums on the spreading of zoonotic parasites, vectors and vector-borne pathogens, 
highlighting the veterinary and public health consequences that the direct and/or indirect contact with these animals may bring for people and domestic animals.

\section{The genus Didelphis: ecology and coexistence with domestic animals and humans}

The genus Didelphis consist of six species generally known as "New World marsupials" or "opossums" (Voss and Jansa 2009). Except for Didelphis virginiana, these animals are classified in two groups: Didelphis marsupialis-group (i.e., Didelphis marsupialis and Didelphis aurita) and Didelphis albiventris-group (i.e., Didelphis albiventris, Didelphis pernigra and Didelphis imperfecta) (Gardner 2008; Faria and de Melo 2017). From the species up to date recognized, $D$. albiventris, $D$. aurita, D. marsupialis and $D$. virginiana are the most abundant and widely distributed (Fig. 2). Three of them are mostly restricted to South America: the white-eared opossum (D. albiventris) occurring in Argentina, Bolivia, Brazil, Paraguay, and Uruguay; the black-eared opossum (D. aurita), found in northeastern Argentina, eastern Brazil, and southeastern Paraguay; and the common opossum (D. marsupialis), which is distributed through Trinidad and Tobago, the Guianas, Mexico, and in the Amazon basin (including Bolivia, Brazil, Colombia, Ecuador, Peru, and Venezuela). Conversely, the Virginia opossum (D. virginiana) is widely distributed and abundant in North and Central America, being reported from Canada to Costa Rica
(Gardner 2008). The other two species (i.e., D. imperfecta and $D$. pernigra) have a more limited distribution being the first restricted to small land range in Venezuela, Brazil, Surinam, and the Guianas, and the second found throughout the Andes region (Gardner 2008).

Species of the genus Didelphis have twilight and nocturnal habits and are considered synanthropic animals due to the high adaptation to human dwellings, being frequently found on the roof of houses, hollows of trees and other shelters within the cities and peripheral areas (Jansen 2002). Due to their circulation in urban and rural environments, opossums are considered potential reservoirs of many infectious agents (e.g., Trypanossoma cruzi, Leishmania infantum, Rickettsia spp., Ancylostoma caninum, Angiostrongylus cantonensis, Angiostrongylus costaricensis) to humans and domestic animals (Miller et al. 2006; Horta et al. 2009, 2010; Carreira et al. 2012; Cantillo-Barraza et al. 2015; Dalton et al. 2017; Bezerra-Santos et al. 2020a). Additionally, ectoparasites (e.g., ticks and fleas) harbored by these animals have been reported as vectors of important arthropod-borne zoonotic pathogens (e.g., Rickettsia spp. and Borrelia spp.) (Hanincová et al. 2006; Horta et al. 2009; Abramowicz et al. 2012; Maina et al. 2016).

Opossums present omnivorous habit and opportunistic feeding behavior, with a diet consisting of small vertebrates, invertebrates, seeds, and fruits (Cáceres and Monteiro-Filho 2001). The feeding behavior of these animals varies according to the seasons of the year, depending on the availability of resource found in each period. For instance, during the rainy
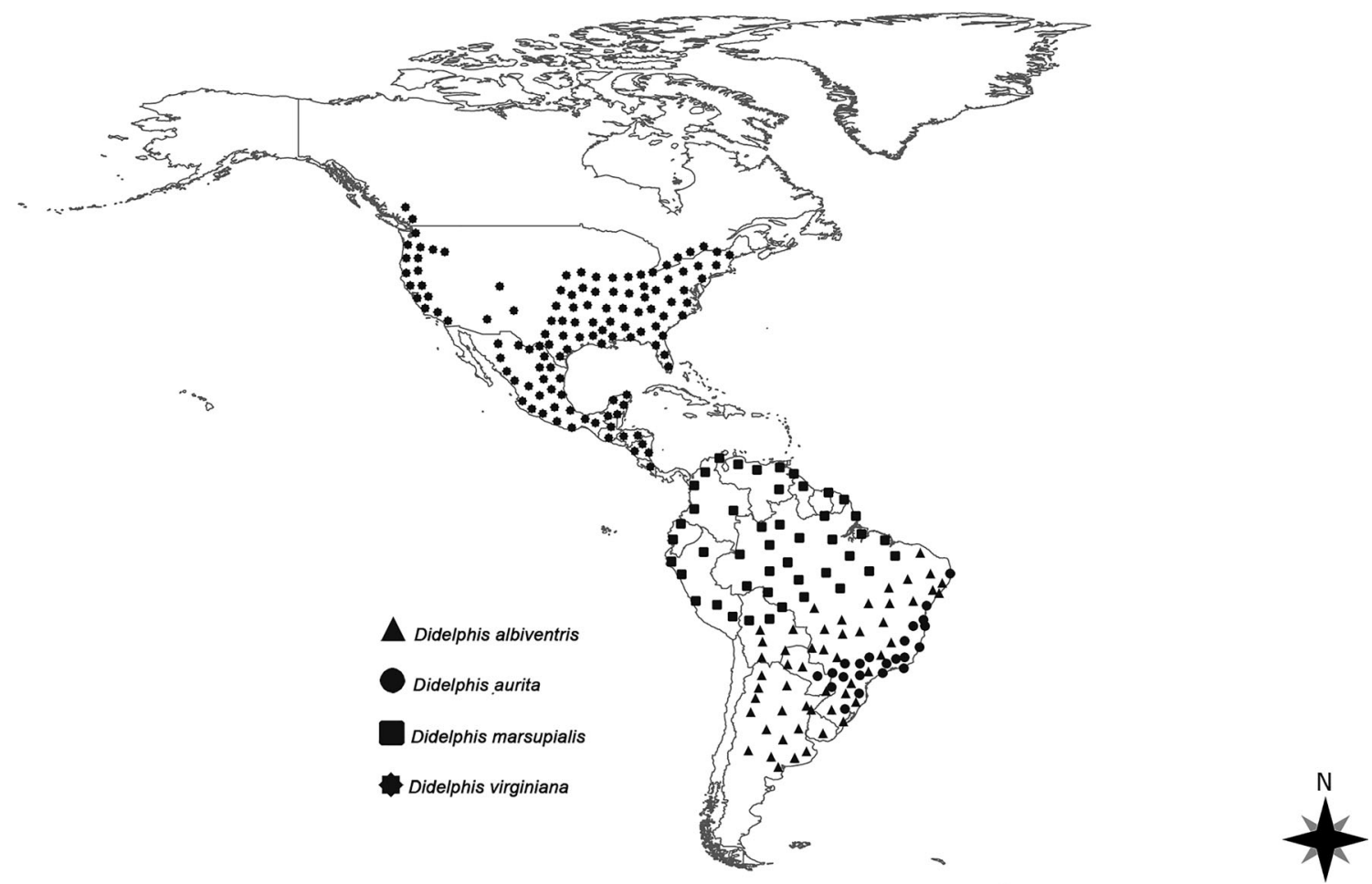

Fig. 2 Geographical distribution of the four major Didelphis spp. in the Americas (Gardner 2008; Pérez-Hernandez et al. 2016). 
season they have higher food intake of fruits and vertebrate animals. Additionally, the diet of these marsupials may differ according to the environment where they are mostly inserted, being possible to record fruits and garbage remnants of human consumption, as well as food only available inside forest fragments (Cáceres and Monteiro-Filho 2001). This opportunistic feeding behavior exposes them to diverse parasitic infections (Jiménez et al. 2011). For instance, by consuming contaminated food from garbage remnants (e.g., garbage contaminated with feces of infected dogs or cats) they may get gastrointestinal parasite infections (e.g., Ancylostoma caninum and Toxocara spp.), and the ingestion of insect vectors (e.g., kissing bugs) may expose them to blood protozoa such as Trypanosoma cruzi (Schweigmann et al. 1995; Teodoro et al. 2019; Bezerra-Santos et al. 2020a).

These marsupials live in close relationship with humans and domestic animals. In many South American countries, some people consider opossums as pests, frequently mistaken them as rats or by considering them dirty animals (Krause and Krause 2006; Barros and Azevedo 2014). This factor leads to their death within the cities using poison or even traps to capture and kill (Fig. 1b) (Stone et al. 2000; Barros and Azevedo 2014). Domestic animals (predominantly dogs) also use to attack opossums, especially during the reproduction period, in which females are slower due to the high number of baby opossums (known as "joeys") they carry on their back or within the marsupium (Fig. 1c, d) (Rangel and Neiva 2013). In rural settings, mainly in poultry farms, opossums are also seen as a problem, since they have been considered important predators of domestic birds, leading to human and wildlife conflicts (Amador-Alcalá et al. 2013).

In their natural habitats, opossums have an irreplaceable ecological role acting in the control of pests (e.g., insects and venomous animals), as well as in the dispersion of seeds, which contribute to the ecology of various plant species because of their mutualistic interactions (Cantor et al. 2010; Voss and Jansa 2012). This behavior makes opossums important for the natural reforestation process of disturbed forest fragments (Cantor et al. 2010). As such, regardless their role in the ecology of zoonotic parasites, these marsupials are not human's enemies, as they are essential contributors for the ecosystem in which they are included. However, given their reservoir role of infectious agents, it is extremely important the establishment of human awareness regarding the prevention of diseases caused by pathogens transmitted by opossums.

\section{Arthropods and vector-borne pathogens associated with Didelphis spp.}

\section{Ticks and tick-borne pathogens}

Ticks are among the vectors of major importance in the transmission of pathogens (e.g., Babesia spp., Ehrlichia spp., Anaplasma spp., Rickettsia spp. and Borrelia spp.) (Dantas-
Torres et al. 2012a; Otranto 2018). These blood-sucking arthropods feed on a great variety of vertebrate hosts, being recorded in humans, domestic animals, and wildlife, including opossums (Soares et al. 2015; Saracho-Bottero et al. 2018; Mendoza-Roldan et al. 2020a). It is known that the exchange of ectoparasites among these hosts has a central importance in the epidemiology of tick-borne diseases. In this perspective, opossums are suggested to play a central role in the epidemiological chain of some tick-borne pathogens, as one of their behaviors (i.e., movement among forests, urban, and rural locations) facilitates the spreading of different tick species from wild environments to urban sites (Bermúdez et al. 2016; Rojero-Vázquez et al. 2017). For example, opossums captured close to human dwellings have been reported harboring species of hard ticks (Amblyomma spp.) (Massini et al. 2019; BezerraSantos et al. 2020b), which are usually found in other wildlife species within forests areas of Brazil (Dantas-Torres et al. 2010). Moreover, the relevance of opossums as potential disseminators of tick-borne pathogens has been suggested by studies on the exposure of these marsupials to tick-borne zoonotic pathogens, such as $R$. rickettsii, B. burgdorferi and Ehrlichia chaffeensis (Horta et al. 2009; Castellaw et al. 2011; Melo et al. 2016). For instance, an experimental study demonstrated that $D$. aurita opossums get infected after being exposed to $R$. rickettsii-positive Amblyomma sculptum ticks, developing rickettsemia capable of causing infection in guinea pigs and ticks, and acting as amplifier hosts of this bacterium to ticks, although the infection rate (i.e., $5 \%$ to $18 \%$ ) in ticks was considered low (Horta et al. 2009). On the other hand, despite seroprevalence of $27.5 \%$ for B. burgdorferi and $15.8 \%$ for E. chaffeensis have been demonstrated in opossums, the role of these animals in the epidemiology of these bacteria is unclear (Castellaw et al. 2011; Melo et al. 2016).

Despite the genus Amblyomma being the most diverse among the ixodid ticks reported on Didelphis spp. in South America (Table 1), most life stages detected are larvae and nymphs (Dantas-Torres et al. 2012b; Saraiva et al. 2012; Sponchiado et al. 2015; Lopes et al. 2018). In contrast, the genus Ixodes is mostly reported on these marsupials as adult stages (Fig. 3), with the species Ixodes loricatus, Ixodes amarali, Ixodes luciae and Ixodes didelphidis having these animals as primary hosts (Labruna et al. 2004, 2009; Dantas-Torres et al. 2012b). Indeed, it is known that they are three host ticks feeding on small rodents at early life stages, and on opossums at the adult stage (Labruna et al. 2009; Nava et al. 2017; Tarragona et al. 2018). Up to date, there is no record on the vector role of these species or their parasitic association with humans. However, transovarial and transstadial transmission of Rickettsia belli, a microorganism of unknown pathogenicity, have been demonstrated in engorged ticks, I. loricatus, collected from $D$. aurita, suggesting that this tick species could have a role in the maintenance of this bacterium in nature (Horta et al. 2006). Further studies 
Table 1 Ticks reported on Didelphis species, occurrence on humans and associated zoonotic pathogens

\begin{tabular}{|c|c|}
\hline supial & Tick species \\
\hline
\end{tabular}

species

on humans

\begin{tabular}{|c|c|c|c|}
\hline \multirow[t]{10}{*}{$\begin{array}{l}\text { Didelphis } \\
\quad \text { albiventris }\end{array}$} & $\begin{array}{l}\text { Ixodidae } \\
\text { Amblyomma } \\
\quad \text { aureolatum }\end{array}$ & Yes & Spotted Fever Group Rickettsiae \\
\hline & $\begin{array}{l}\text { Amblyomma } \\
\text { auricularium }\end{array}$ & Yes & No record \\
\hline & $\begin{array}{l}\text { Amblyomma } \\
\text { coelebs }\end{array}$ & Yes & No record \\
\hline & $\begin{array}{r}\text { Amblyomma } \\
\text { dubitatum }\end{array}$ & Yes & Spotted Fever Group Rickettsiae \\
\hline & $\begin{array}{l}\text { Amblyomma } \\
\quad \text { fuscum }\end{array}$ & Yes & No record \\
\hline & $\begin{array}{l}\text { Amblyomma } \\
\text { ovale }\end{array}$ & Yes & Spotted Fever Group Rickettsiae \\
\hline & $\begin{array}{c}\text { Amblyomma } \\
\text { sculptum }\end{array}$ & Yes & Spotted Fever Group Rickettsiae \\
\hline & $\begin{array}{l}\text { Amblyomma } \\
\text { parkeri }\end{array}$ & Yes & Rickettsia parkeri \\
\hline & Ixodes loricatus & No record & No record \\
\hline & $\begin{array}{l}\text { Argasidae } \\
\text { Ornithodoros } \\
\quad \text { mimon }\end{array}$ & Yes & No record \\
\hline \multirow[t]{17}{*}{$\begin{array}{l}\text { Didelphis } \\
\text { aurita }\end{array}$} & $\begin{array}{l}\text { Ixodidae } \\
\text { Amblyomma } \\
\quad \text { aureolatum }\end{array}$ & Yes & Spotted Fever Group Rickettsiae \\
\hline & $\begin{array}{l}\text { Amblyomma } \\
\text { brasiliense }\end{array}$ & Yes & No record \\
\hline & $\begin{array}{l}\text { Amblyomma } \\
\text { coelebs }\end{array}$ & Yes & No record \\
\hline & $\begin{array}{r}\text { Amblyomma } \\
\text { dubitatum }\end{array}$ & Yes & Spotted Fever Group Rickettsiae \\
\hline & $\begin{array}{l}\text { Amblyomma } \\
\text { fuscum }\end{array}$ & Yes & No record \\
\hline & $\begin{array}{l}\text { Amblyomma } \\
\text { geayi }\end{array}$ & No record & Rickettsia amblyommatis \\
\hline & $\begin{array}{l}\text { Amblyomma } \\
\text { incisum }\end{array}$ & Yes & No record \\
\hline & $\begin{array}{l}\text { Amblyomma } \\
\text { ovale }\end{array}$ & Yes & Spotted Fever Group Rickettsiae \\
\hline & $\begin{array}{l}\text { Amblyomma } \\
\text { sculptum }\end{array}$ & Yes & Spotted Fever Group Rickettsiae \\
\hline & $\begin{array}{l}\text { Amblyomma } \\
\text { scutatum }\end{array}$ & No record & No record \\
\hline & $\begin{array}{l}\text { Amblyomma } \\
\text { yucumense }\end{array}$ & No record & No record \\
\hline & $\begin{array}{l}\text { Haemaphysalis } \\
\text { juxtakochi }\end{array}$ & Yes & $\begin{array}{l}\text { Rickettsia parkeri, Borrelia burgdorferi } \\
\text { sensu lato }\end{array}$ \\
\hline & Ixodes amarali & No record & No record \\
\hline & Ixodes auritulus & No record & $\begin{array}{l}\text { Borrelia burgdorferi sensu stricto, } \\
\text { Borrelia burgdorferi sensu lato }\end{array}$ \\
\hline & $\begin{array}{l}\text { Ixodes } \\
\quad \text { didelphidis }\end{array}$ & No record & No record \\
\hline & Ixodes loricatus & No record & No record \\
\hline & Ixodes luciae & No record & No record \\
\hline \multirow{6}{*}{$\begin{array}{l}\text { Didelphis } \\
\quad \text { marsupialis }\end{array}$} & Ixodidae & & \\
\hline & $\begin{array}{l}\text { Amblyomma } \\
\text { cajennense } \\
\text { sensu stricto }\end{array}$ & No record & Rickettsia amblyommatis \\
\hline & $\begin{array}{l}\text { Amblyomma } \\
\text { coelebs }\end{array}$ & Yes & No record \\
\hline & $\begin{array}{l}\text { Amblyomma } \\
\text { dissimile }\end{array}$ & Yes & Rickettsia monacensis \\
\hline & $\begin{array}{l}\text { Amblyomma } \\
\text { geavi }\end{array}$ & No record & Rickettsia amblyommatis \\
\hline & & No record & Rickettsia amblyommatis \\
\hline
\end{tabular}

Muller et al. (2005); Barbieri et al. (2015); Moraes-Filho et al. (2018); Reck et al. (2018)

Fontalvo et al. (2017); Szabó et al. (2020)

Garcia et al. (2015); Sponchiado et al. (2015); De Sá et al. (2018)

Sakai et al. (2014); Matias et al. (2015); Sponchiado et al. (2015); Lamattina and Nava (2016); Reck et al. (2018); De Sá et al. (2018)

Marques et al. (2006); Martins et al. (2009); Dantas-Torres et al. (2012b)

Barbieri et al. (2015); Sponchiado et al. (2015); Reck et al. (2018); Lamattina et al. (2018a)

Sponchiado et al. (2015); Bitencourth et al. (2017); Polo et al. (2017); De Sá et al. (2018); Saracho-Bottero et al. (2018)

Sponchiado et al. (2015); Zeringóta et al. (2017); Reck et al. (2018); Borsoi et al. (2019)

Muller et al. (2005); Horta et al. (2007); Dantas-Torres et al. (2012b); da Silva et al. (2017); De Sá et al. (2018)

Labruna et al. (2014); Sponchiado et al. (2015); da Silva et al. (2017)

Salvador et al. (2007); Barbieri et al. (2015); Luz et al. (2018); Moraes-Filho et al. (2018); Reck et al. (2018)

Szabó et al. (2006); Szabó et al. (2013); Lamattina et al. (2018a, 2018b)

Saraiva et al. (2012); Garcia et al. (2015); Lamattina et al. (2018a, 2018b)

Horta et al. (2007); Sakai et al. (2014); Matias et al. (2015); Lamattina and Nava (2016); Reck et al. (2018)

Marques et al. (2006); Martins et al. (2009); Dantas-Torres et al. (2012b); Szabó et al. (2013)

Oliveira et al. 2014; Dolz et al. 2019

Szabó et al. (2006); Reck et al. (2018); Lamattina et al. (2018a, b)

Szabó et al. (2013); Barbieri et al. (2015); Lamattina et al. (2018a, b); Reck et al. (2018)

Salvador et al. (2007); Saraiva et al. (2012); Szabó et al. (2013); Bitencourth et al. (2017); Polo et al. (2017); Saracho-Bottero et al. (2018)

Oliveira et al. (2014)

Krawczak et al. (2015)

Lamattina et al. (2018a); Reck et al. (2018); Saracho-Bottero et al. (2018); Souza et al. (2018); Flores et al. (2018)

Oliveira et al. (2014)

Morshed et al. (2005); Oliveira et al. (2014); Carvalho et al. (2020)

Barros-Battesti et al. (2000); Oliveira et al. (2014)

Horta et al. (2007); Salvador et al. (2007); Dantas-Torres et al. (2012b); Saraiva et al. (2012); Szabó et al. (2013); Oliveira et al. (2014); Luz et al. (2018)

Oliveira et al. (2014)

Costa et al. (2017); Binetruy et al. (2019)

Garcia et al. (2015); Witter et al. (2016); Binetruy et al. (2019)

Guglielmone et al. (2006); Domínguez et al. (2019);

Mendoza-Roldan et al. (2021)

Soares et al. (2015); Dolz et al. (2019) 
Table 1 (continued)

\begin{tabular}{|c|c|c|c|c|}
\hline $\begin{array}{l}\text { Marsupial } \\
\text { species }\end{array}$ & Tick species & $\begin{array}{l}\text { Occurrence } \\
\text { on humans }\end{array}$ & Associated zoonotic pathogens & Reference \\
\hline & $\begin{array}{l}\text { Amblyomma } \\
\text { humerale }\end{array}$ & & & $\begin{array}{l}\text { Soares et al. (2015); Witter et al. 2016, Binetruy et al. (2019); } \\
\text { Gruhn et al. (2019) }\end{array}$ \\
\hline & $\begin{array}{l}\text { Amblyomma } \\
\text { mixtum }\end{array}$ & Yes & Rickettsia rickettsii, Coxiella Burnetii & $\begin{array}{l}\text { Bermúdez et al. (2016); Noda et al. (2016); Rodríguez-Vivas et al. } \\
\text { (2016); Domínguez et al. (2019) }\end{array}$ \\
\hline & $\begin{array}{l}\text { Amblyomma } \\
\text { oblongogutta- } \\
\text { tum }\end{array}$ & Yes & Rickettsia amblyommatis & $\begin{array}{l}\text { Bermúdez et al. (2012); Aguirre et al. (2018); Domínguez et al. } \\
\text { (2019) }\end{array}$ \\
\hline & $\begin{array}{l}\text { Amblyomma } \\
\quad \text { ovale }\end{array}$ & Yes & Spotted Fever Group Rickettsiae & $\begin{array}{l}\text { Barbieri et al. (2015); Lamattina et al. (2018b); Reck et al. (2018); } \\
\text { Domínguez et al. (2019) }\end{array}$ \\
\hline & $\begin{array}{l}\text { Amblyomma } \\
\text { pacae }\end{array}$ & Yes & No record & Guglielmone et al. (2006); Soares et al. (2015) \\
\hline & $\begin{array}{l}\text { Amblyomma } \\
\text { parkeri }\end{array}$ & Yes & Rickettsia parkeri & $\begin{array}{l}\text { Witter et al. (2016); Zeringóta et al. (2017); Reck et al. (2018); } \\
\text { Borsoi et al. (2019) }\end{array}$ \\
\hline & $\begin{array}{l}\text { Amblyomma } \\
\text { sabanerae }\end{array}$ & Yes & No record & Bermúdez et al. (2012); Domínguez et al. (2019) \\
\hline & $\begin{array}{l}\text { Amblyomma } \\
\text { sculptum }\end{array}$ & Yes & Spotted Fever Group Rickettsiae & $\begin{array}{l}\text { de Lemos et al. (1996); Bitencourth et al. (2017); Polo et al. } \\
\text { (2017); Saracho-Bottero et al. (2018) }\end{array}$ \\
\hline & $\begin{array}{l}\text { Amblyomma } \\
\text { triste }\end{array}$ & Yes & Rickettsia parkeri & $\begin{array}{l}\text { de Lemos et al. (1996); Guglielmone et al. (2006); Melo et al. } \\
\text { (2015) }\end{array}$ \\
\hline & $\begin{array}{l}\text { Haemaphysalis } \\
\text { juxtakochi }\end{array}$ & Yes & $\begin{array}{l}\text { Rickettsia parkeri; Borrelia } \\
\text { burgdorferi sensu lato }\end{array}$ & $\begin{array}{l}\text { Flores et al. (2018); Souza et al. (2018); Reck et al. (2018); } \\
\text { Saracho-Bottero et al. (2018); Domínguez et al. (2019) }\end{array}$ \\
\hline & $\begin{array}{l}\text { Ixodes } \\
\quad \text { didelphidis }\end{array}$ & No record & No record & Abel et al. (2000) \\
\hline & Ixodes loricatus & No record & No record & Abel et al. (2000) \\
\hline & Ixodes luciae & No record & No record & Domínguez et al. (2019); Binetruy et al. (2019) \\
\hline & $\begin{array}{l}\text { Rhipicephalus } \\
\text { sanguineus } \\
\text { sensu lato }\end{array}$ & Yes & $\begin{array}{r}\text { Rickettsia rickettsii, Bartonella } \\
\text { henselae, Rickettsia conorii }\end{array}$ & $\begin{array}{l}\text { Goddard (1989); Kollars (1993); Matsumoto et al. (2005); } \\
\text { Dantas-Torres et al. (2006); Wikswo et al. (2007); Otranto et al. } \\
\text { (2014); Bermúdez et al. (2016); Reck et al. (2018) }\end{array}$ \\
\hline \multirow{9}{*}{$\begin{array}{l}\text { Didelphis } \\
\quad \text { virginiana }\end{array}$} & Ixodidae & & & \\
\hline & $\begin{array}{l}\text { Amblyomma } \\
\text { americanum }\end{array}$ & Yes & $\begin{array}{l}\text { Ehrlichia chaffeensis, Ehrlichia } \\
\text { ewingii, Rickettsia rickettsii, } \\
\text { Coxiella burnetii, Francisella tularensis, } \\
\text { Borrelia lonestari, Rickettsia parkeri }\end{array}$ & $\begin{array}{l}\text { Kollars (1993); Lavender and Oliver (1996); Oliver et al. (1999); } \\
\text { Childs and Paddock (2003); Levin et al. (2017) }\end{array}$ \\
\hline & $\begin{array}{l}\text { Dermacentor } \\
\text { variabilis }\end{array}$ & Yes & $\begin{array}{l}\text { Spotted Fever Group Rickettsiae, Francisella } \\
\text { tularensis, Ehrlichia chaffeensis, Ehrlichia } \\
\text { ewingii }\end{array}$ & $\begin{array}{l}\text { Fish and Dowler (1989); Kollars (1993); Lavender and Oliver } \\
\text { (1996); Oliver et al. (1999); Steiert and Gilfoy (2002); } \\
\text { Stromdahl et al. (2011); Hecht et al. (2019); Whitten et al. } \\
\text { (2019) }\end{array}$ \\
\hline & Ixodes affinis & No record & $\begin{array}{l}\text { Borrelia burgdorferi, Borrelia bissettiae, } \\
\text { Bartonella henselae }\end{array}$ & Lavender and Oliver (1996); Maggi et al. (2019) \\
\hline & Ixodes cookei & Yes & Borrelia burgdorferi, Babesia microti & Fish and Dowler (1989); Hall et al. (1991); Scott et al. (2019) \\
\hline & $\begin{array}{l}\text { Ixodes } \\
\qquad \text { scapularis }\end{array}$ & Yes & $\begin{array}{l}\text { Borrelia burgdorferi sensu stricto, Borrelia } \\
\text { mayoni, Borrelia miyamoto, Ehrlichia muris } \\
\text { eauclarensis, Babesia microti }\end{array}$ & $\begin{array}{l}\text { Kollars (1993); Lavender and Oliver (1996); Oliver et al. (1999); } \\
\text { Eisen and Eisen (2018); Xu et al. } 2019\end{array}$ \\
\hline & Lxodes texanus & Yes & Borrelia burgdorferi, Rickettsia rickettsii & $\begin{array}{l}\text { Anderson et al. (1986); Fish and Dowler (1989); Hall et al. (1991); } \\
\text { Ouellette et al. (1997) }\end{array}$ \\
\hline & $\begin{array}{l}\text { Haemaphysalis } \\
\text { longicornis }\end{array}$ & Yes & $\begin{array}{l}\text { severe fever with thrombocytopenia syndrome } \\
\text { virus, Anaplasma spp., Rickettsia } \text { spp., Babesia } \\
\text { spp., Theileria } \text { spp., Borrelia } \text { spp. }\end{array}$ & Tufts et al. (2020) \\
\hline & $\begin{array}{l}\text { Rhipicephalus } \\
\text { sanguineus } \\
\text { sensu lato }\end{array}$ & Yes & $\begin{array}{l}\text { Rickettsia rickettsii, Bartonella henselae, } \\
\text { Rickettsia conorii }\end{array}$ & $\begin{array}{l}\text { Goddard (1989); Kollars (1993); Matsumoto et al. (2005); } \\
\text { Dantas-Torres et al. (2006); Wikswo et al. (2007); Otranto et al. } \\
\text { (2014); Reck et al. (2018) }\end{array}$ \\
\hline Didelphis & Ixodidae & & & \\
\hline imperfecta & $\begin{array}{l}\text { Amblyomma } \\
\text { cajennense } \\
\text { sensu stricto }\end{array}$ & No record & Rickettsia amblyommatis & Costa et al. (2017); Binetruy et al. (2019) \\
\hline
\end{tabular}

are advocated on the vector role and host range of these species, as some of them (e.g., I. loricatus) have been the main and most abundant ticks found on Didelphis spp. from urban and rural environments (Dantas-Torres et al. 2012b; Tarragona et al. 2018; Bezerra-Santos et al. 2020b). Thus, identifying their potential role on the epidemiology of tickborne pathogens affecting humans and/or domestic animals is important from a One Health perspective. A single species of the genus Haemaphysalis (i.e., Haemaphysalis juxtakochi) has been recorded on D. aurita and D. marsupialis (Lamattina et al. 2018a, b; Domínguez et al. 2019). This species is known as the neotropical deer tick and has also been reported on other wildlife species, humans, and domestic animals (Costa et al. 2017; Saracho-Bottero et al. 2018). In 
addition, some zoonotic pathogens such as Rickettsia parkeri and $B$. burgdorferi sensu lato have been detected in H. juxtakochi, although its role in the transmission of these pathogens to humans is probable negligible (Souza et al. 2018; Flores et al. 2018).

Different tick species have been reported on the Virginia opossum due to its distinct geographical range as compared to other species of the same genus (Fig. 2). Up to date, Amblyomma americanum, Dermacentor variabilis, Haemaphysalis longicornis, and five species of the genus Ixodes have been recorded on this opossum (Table 1). However, despite the medical and veterinary importance of these ticks, their relationship with opossums needs further investigation, particularly regarding their ability to acquire pathogens from opossums, as well as the capacity of opossums to serve as amplifier hosts. Most recently, the Virginia opossum has been found commonly infested by H. longicornis (Table 1), an invasive Asian tick, in some states of the USA (Tufts et al. 2020; White et al. 2020). This tick species has been associated with several vector-borne pathogens (e.g., Anaplasma spp., Rickettsia spp., Babesia spp., Theileria spp., Borrelia spp.) in its native range. However, its potential to serve as vector for pathogens of medical and veterinary importance in USA is still poorly understood (Tufts et al. 2020). Indeed, under laboratory conditions, $H$. longicornis larvae and nymphs became infected with $R$. rickettsii after feeding on infected guinea pigs and were able to transmit them to naïve guinea pigs (Stanley et al. 2020). In addition, the same study also demonstrated the transstadial and transovarial transmission of $R$. rickettsii in the same tick species (Stanley et al. 2020). Lastly, Rhipicephalus sanguineus sensu lato (s.1.) infesting opossums are rare, being described only in $D$. virginiana and D. marsupialis (Kollars 1993; Bermúdez et al. 2016). Thus, the capacity of opossums to maintain this tick species population, as well as the sharing of pathogens have not been assessed and seem unlikely.

\section{Fleas and flea-borne pathogens}

Opossums harbor a great diversity of flea species (Horta et al. 2007; Pinto et al. 2009; Urdapilleta et al. 2019; Bezerra-Santos et al. 2020b; Canto-Osorio et al. 2020), with some of them being regarded as important vectors of zoonotic pathogens (e.g., Ctenocephalides felis felis, Xenopsylla cheopis, Pulex irritans and Pulex simulans), while others (e.g., Adoratopsylla antiquorum, Polygenis occidentalis and Cediopsylla simplex) presenting unknown vector role as studies on their ecology and epidemiology are scanty (Table 2). Among the pathogens transmitted by fleas reported on Didelphis spp., R. typhi, R. felis and Y. pestis are of major public health concern (Azad et al. 1997; Demeure et al. 2019; Oliveira et al. 2020). Rickettsia typhi is the etiological agent of the murine typhus, a worldwide distributed zoonosis with a life cycle involving rodents (Rattus rattus and Rattus norvegicus) as vertebrate hosts, and fleas ( $X$. cheopis) as vectors (PenicheLara et al. 2015). This pathogen has also been reported through molecular methods in C. felis felis, Leptopsylla segnis, Ctenophthalmus congeneroides and Rhadinopsylla insolita (Peniche-Lara et al. 2015). The transmission occurs from rodents to humans through contaminated feces of infected fleas. Despite the rodents being the main hosts of $R$. typhi, opossums were infected with this bacterium in the USA and are believed to have important role on the epidemiology of the disease (Williams et al. 1992; Sorvillo et al. 1993; Brown and Macaluso 2016). Another important pathogen transmitted by fleas is the $R$. felis, a worldwide distributed rickettsia that causes the flea-borne spotted fever. This bacterium may be transmitted by several flea species but has the $C$. felis felis as its main vector (Angelakis et al. 2016). Just like in the murine typhus, opossums are suggested as potential reservoirs of R. felis (Boostrom et al. 2002; Brown and Macaluso 2016). For instance, studies performed on $D$. virginiana reported high seroprevalence for $R$. felis (i.e., 22\%) as well as the presence of the bacterium DNA in tissue (e.g., spleen, liver, and kidney) and in $C$. felis felis fleas collected on them (Boostrom et al. 2002; Karpathy et al. 2009; Panti-May et al. 2015). However, the role played by these animals as reservoir of $R$. felis may vary according to the opossum species and further investigations are needed, since undetectable rickettsemia was reported in D. aurita in Brazil following experimental infection (Horta et al. 2010). Fleas are also known as vectors of the deadly bacteria Y. pestis (Pechous et al. 2016). Up to date, this bacterium has been detected through serological and bacterial culture in D. albiventris in Brazil (Almeida et al. 1987; Almeida et al. 1995). Indeed, considering the infestation of the main vector of this bacterium (i.e., $X$. cheopis) on D. aurita (Bezerra-Santos et al. 2020b), it is worth to further investigate the role of these animals as reservoir of this pathogen.

\section{Phlebotomine sand flies and leishmaniasis}

Opossums have been identified as a blood source for several hematophagous arthropods, including phlebotomine sand flies (e.g., Lutzomyia longipalpis and Lutzomyia evansi), which are accounted as vectors of pathogenic Leishmania spp. (Adler et al. 2003; Guimarães-e-Silva et al. 2017) such as $L$. infantum, the etiological agent of American visceral leishmaniasis (Spiegel et al. 2016; Mejía et al. 2018). Indeed, natural and experimental infection with species of zoonotic Leishmania (e.g., L. infantum, L. brasiliensis) in Didelphis spp. confirm their participation in the sylvatic and peridomestic cycles of these protozoa (Schallig et al. 2007; Carreira et al. 2012; Humberg et al. 2012; Silva et al. 2016). Natural infection by different Leishmania spp. has been reported in these marsupials in the New World (Table 3) 
Fig. 3 Ixodes loricatus adults collected on Didelphis aurita opossums. Female dorsal (a) and ventral view (b). Male dorsal (c) and ventral view (d).

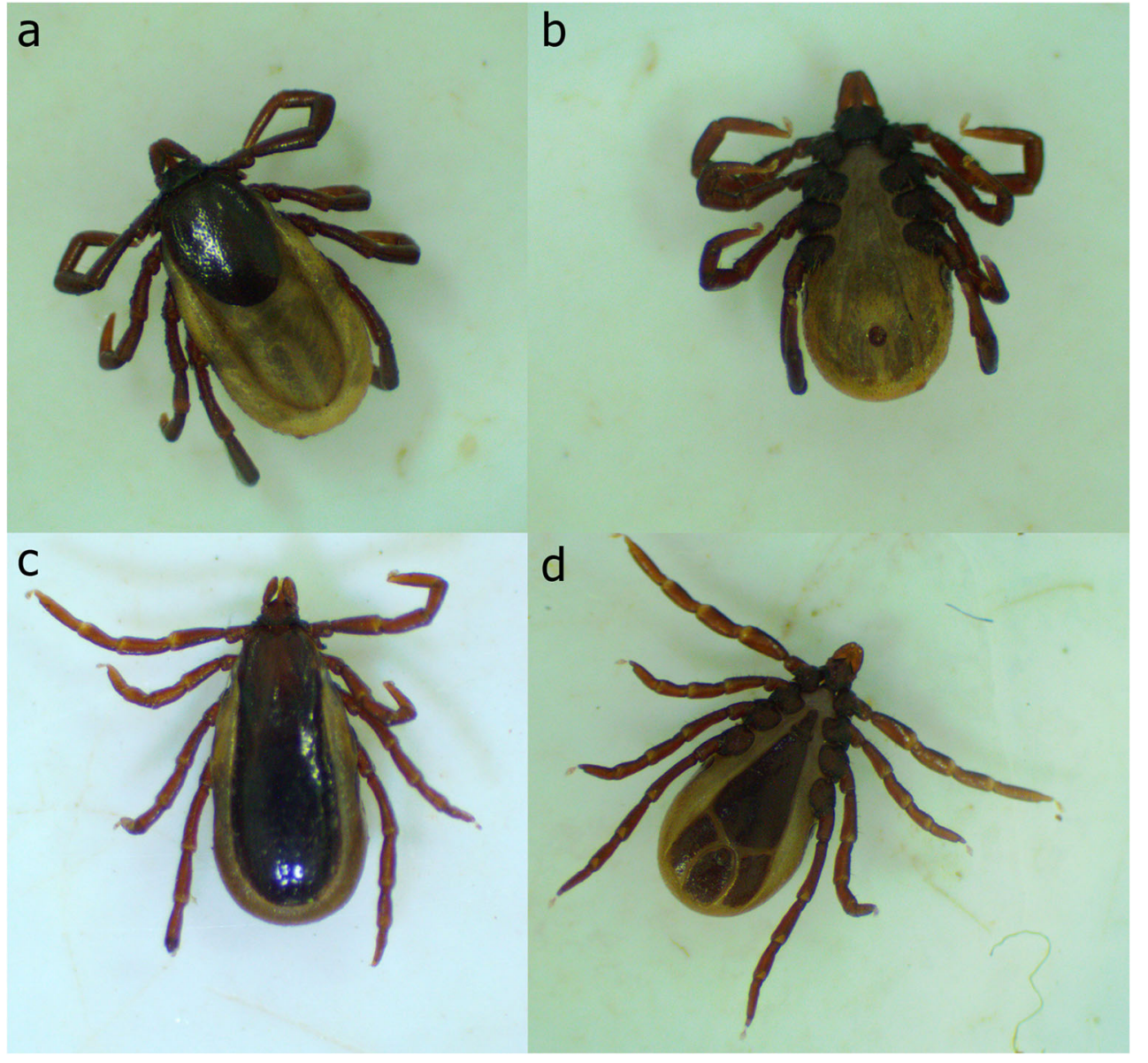

(Santiago et al. 2007; Quintal et al. 2011; Carreira et al. 2012; Lima et al. 2013; Silva et al. 2016; Maia et al. 2018). For example, in urban and peri-urban areas of Southeastern Brazil, D. albiventris and D. aurita opossums displayed a high prevalence (i.e., $91.96 \% ; n=103 / 112$ ) of $L$. infantum through PCR screening of DNA isolated from bone marrow, supporting their role as hosts of the causative agent of visceral leishmaniasis (Santiago et al. 2007). The role of marsupials in the epidemiology of this disease has been observed particularly in areas with peridomestic transmission, where phlebotomine sand flies may feed on opossums and eventually on other susceptible hosts, including people and domestic animals (e.g., dogs, cats), with opossums being suggested as a link in the transmission of visceral leishmaniasis to humans and dogs in rural and urban environments (Carranza-Tamayo et al. 2016). This has been further supported in an endemic area of Northeastern Brazil, where it was demonstrated that the months with higher opossum population density (rainy and colder) correlates with the peak of Lu. longipalpis population and with new cases of visceral leishmaniasis in humans (Sherlock 1996). In the same study D. albiventris capacity to infect Lu. longipalpis with L. infantum was confirmed through xenodiagnoses, in which $14 \%(n=27 / 193)$ of the sand flies scored positive for this protozoan after feeding on a naturally infected opossum (Sherlock 1996). Data were confirmed through the experimental infection of D. marsupialis with L. infantum, which was able to infect Lu. longipalpis following blood feeding on this opossum species (Travi et al. 1998). In addition, though a small proportion (i.e., $2.6 \% ; n=8 / 312$ ) of sand flies got infected after feeding on $D$. marsupialis, a high attraction rate for sand flies in trapped opossums was registered by the authors, strengthening their possible role as reservoirs for L. infantum (Travi et al. 1998). Finally, the detection of human and $D$. albiventris DNA in $L u$. longipalpis, allowed to establish a link between these two hosts in an area of Brazil endemic for visceral and cutaneous leishmaniasis (Guimarães-e-Silva et al. 2017).

\section{Triatomines and Trypanosoma cruzi}

Trypanosoma cruzi is the etiological agent of Chagas disease, a neglected tropical illness mostly associated to poor housing conditions of the population in developing countries (Barbosa-Silva et al. 2019). Opossums play an important role in the zoonotic cycle of T. cruzi (Legey et al. 2003; CantilloBarraza et al. 2015; Jansen et al. 2015, 2017). This protozoan may be transmitted to humans via fecal matter of its insect vectors (i.e., triatomines) or by the consumption of 


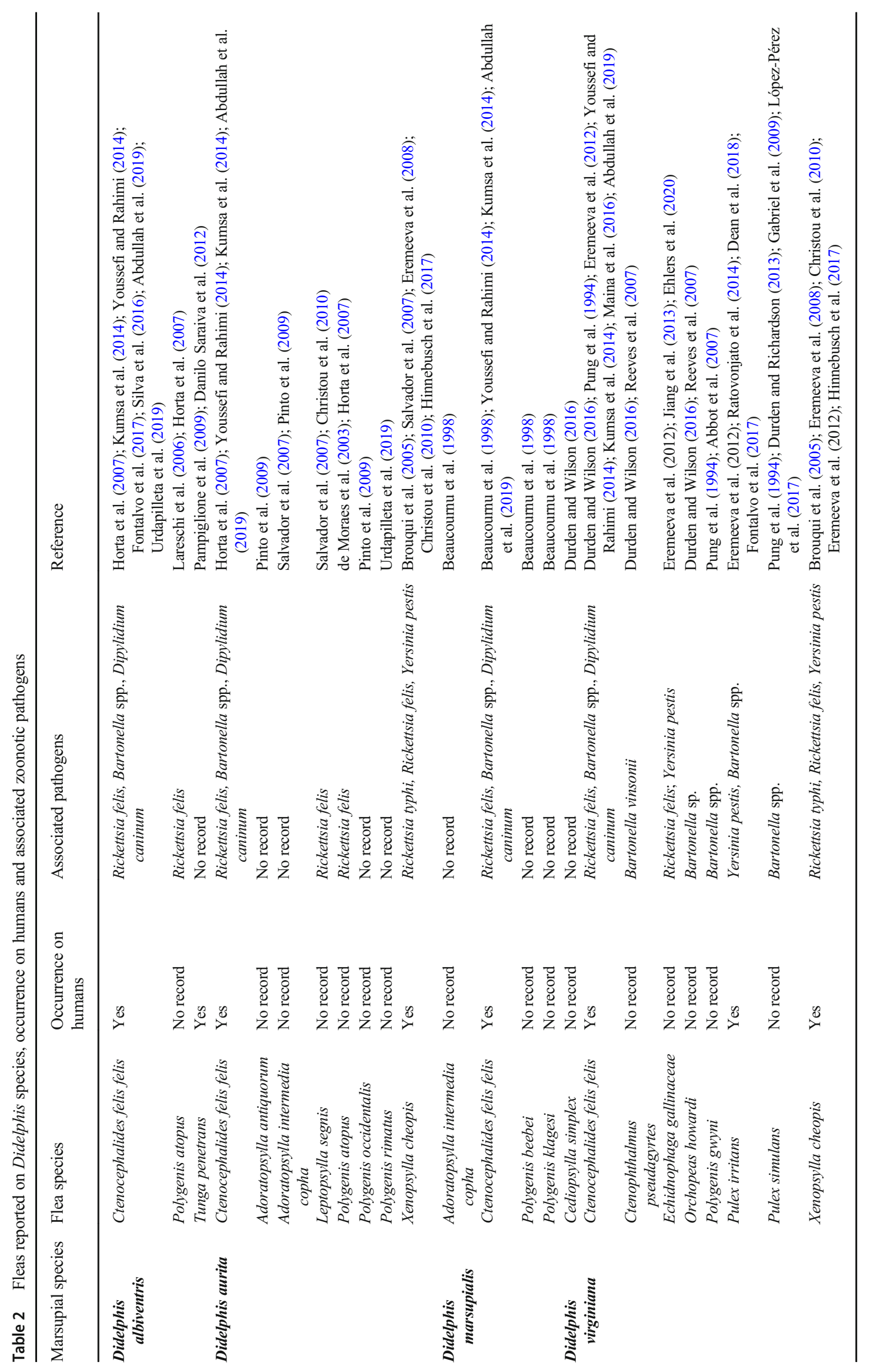


contaminated food due to the presence of infected triatomines during the preparation of food items (e.g., açaí palm fruit, sugar cane, mango), ingestion of raw meat of infected animals, and through breast feeding (de Noya and González 2015; Santana et al. 2019). Didelphis spp. may be associated with both transmission routes in the epidemiological cycle of T. cruzi (Jansen et al. 2015, 2017). Indeed, the interaction of these opossums with triatomine insects (i.e., detection of opossums blood in triatomines, and infection of opossums after being exposed to infected triatomines), as well as the high prevalence of $T$. cruzi infecting the anal glands (optimal microenvironment for the development of infective metacyclic stages of this parasite) of these marsupials suggest their participation in the epidemiological cycle involving vector and oral transmission of T. cruzi (Steindel et al. 1988; Schweigmann et al. 1995; Urdaneta-Morales and Nironi 1996; Zecca et al. 2020). For example, bloodmeal analysis of $T$. cruzi-infected triatomine (Triatoma gerstaeckeri) collected in a dog shelter in South Texas, USA revealed the presence of canine, opossum, and human blood, suggesting the exchange of this protozoan among these hosts (i.e., opossums, dogs and humans) around urban dwellings, and the participation of opossums in the spreading of $T$. cruzi in endemic areas as these animals are known to circulate among different geographical sites (Zecca et al. 2020).

The presence of T. cruzi in opossum's anal glands has been suggested as an oral transmission route since infective forms of this protozoan can be released in the environment, contaminate food, or directly, skin and mucosa of susceptible hosts (Steindel et al. 1988; Urdaneta-Morales and Nironi 1996). This has been demonstrated through the oral infection of mice with metacyclic forms obtained from the anal glands of Didelphis spp. (Steindel et al. 1988; Urdaneta-Morales and Nironi 1996), which led to the suggestion of the involvement of opossums in Chagas disease outbreaks via oral infection in areas where the presence of insect vectors was not detected (Steindel et al. 1988). Additionally, the use of these marsupials as food source for humans may also be implicated as a potential risk for the transmission of $T$. cruzi due to the consumption of undercooked opossum meat (Carvalho et al. 2020; Sangenis et al. 2015; Sangenis et al. 2016).

\section{Endoparasites associated with Didelphis spp.}

\section{Helminths}

Zoonotic helminths parasitizing opossums of the genus Didelphis have been reported throughout the American continent (Table 3), with some species being considered accidental parasitism (e.g., Toxocara cati in D. albiventris; Pinto et al. 2014) and others being recently identified with high prevalence rates (e.g., Ancylostoma caninum in D. aurita; Bezerra-Santos et al. 2020a). Among the helminth species harbored by opossums, Trichinella spiralis, Angiostrongylus cantonensis, Angiostrongylus costaricensis, Paragonimus spp., Alaria marcianae, and Echinostoma spp. (Table 3) present major public health importance due to the disease they cause in humans. Trichinella spiralis is a zoonotic nematode worldwide distributed and transmitted to humans by the ingestion of undercooked meat, especially pork (Diaz et al. 2020). The advances in hygiene in the pork industry has made the transmission of this parasite via commercial pork meat less prone to occur; therefore, the consumption of raw or undercooked meat of wildlife reservoirs (e.g., wild boar, bear, deer, moose, and walrus) is now the most frequent form of transmission (Diaz et al. 2020). In this perspective, the occurrence of $T$. spiralis in Didelphis spp. has a great epidemiological importance and should be considered for investigation, as these animals' meat, usually from non-legalized game hunting, are consumed by humans in many regions of South America (Júnior et al. 2010; Barros and Azevedo 2014; de Oliveira Carneiro et al. 2019). Opossums have also been reported harboring A. cantonensis (Kim et al. 2002; Dalton et al. 2017), a zoonotic nematode recognized as a primary cause of eosinophilic meningitis in humans (Wang et al. 2008; Barratt et al. 2016). The biological cycle of this nematode involves rats as definitive hosts, snails, and slugs as intermediate hosts, and crustaceans, predacious land planarians, frogs, and lizards as paratenic hosts (Mendoza-Roldan et al. 2020b), as well as the transmission of infective L3 from an infested snail to another (i.e., intermediesis; Modrý et al. 2020). Humans become infected by ingesting third-stage larvae (L3) present in intermediate or in paratenic hosts, as well as contaminated vegetables (Wang et al. 2008). Up to date, this nematode has been detected only in D. virginiana; infected individuals present weakness, ataxia and neurological abnormalities such as circling due to the presence of adult worms in the brain tissue (Kim et al. 2002; Dalton et al. 2017). Angiostrongylus costaricensis has also been reported in a $D$. virginiana opossum causing localized peritonitis with adhesions from omentum and presence of adult worms (24 females and 12 males) in the mesenteric arteries (Miller et al. 2006). Similarly, to A. cantonensis, the life cycle of A. costaricensis also involves rats as definitive hosts, and snails and slugs as intermediate hosts, with human and other mammal infections happening through the ingestion of intermediate hosts containing L3, as well as of contaminated vegetables (Miller et al. 2006). The role of opossums in the biological life cycle of A. cantonensis and A. costaricensis is still unknown and deserves further studies.

Opossums have also been reported harboring zoonotic trematodes, such as lung flukes of the genus Paragominus, with the species Paragonimus caliensis, Paragonimus kellicotti, and Paragominus mexicanus being described in these marsupials in the Americas (Table 3) (Blair et al. 1999; López-Caballero et al. 2013). These parasites have a 
Table 3 Zoonotic helminths and protozoa reported in Didelphis species

\begin{tabular}{|c|c|c|}
\hline Marsupial species & Endoparasites & Reference \\
\hline \multirow[t]{11}{*}{ Didelphis albiventris } & Helminths & \\
\hline & Toxocara cati (Nematoda) & Pinto et al. (2014) \\
\hline & Trichinella spiralis (Nematoda) & Castaño Zubieta et al. (2014) \\
\hline & Schistosoma mansoni (Trematoda) & Kawazoe et al. (1978) \\
\hline & Paragominus mexicanus (Trematoda) & Blair et al. (1999) \\
\hline & Protozoa & \\
\hline & Leishmania amazonensis & Maia et al. (2018) \\
\hline & Leishmania braziliensis & Silva et al. (2016) \\
\hline & Leishmania infantum & Humberg et al. (2012) \\
\hline & Toxoplasma gondii & Fornazari et al. (2011) \\
\hline & Trypanosoma cruzi & Lima et al. (2012); Tenório et al. (2014); Drozino et al. (2019) \\
\hline \multirow[t]{7}{*}{ Didelphis aurita } & Helminths & \\
\hline & Ancylostoma caninum (Nematoda) & Bezerra-Santos et al. (2020a) \\
\hline & Schistosoma mansoni (Trematoda) & Coelho et al. (1979) \\
\hline & Protozoa & \\
\hline & Leishmania infantum & Carreira et al. (2012) \\
\hline & Toxoplasma gondii & Pena et al. (2011); Bezerra-Santos et al. (2020c) \\
\hline & Trypanosoma cruzi & Teodoro et al. (2019) \\
\hline \multirow[t]{13}{*}{ Didelphis marsupialis } & Helminths & \\
\hline & Schistosoma haematobium (Trematoda) & Kuntz et al. (1971); Kuntz et al. (1975) \\
\hline & Paragonimus caliensis (Trematoda) & Blair et al. (1999) \\
\hline & Paragominus mexicanus (Trematoda) & Blair et al. (1999); López-Caballero et al. (2013) \\
\hline & Protozoa & \\
\hline & Leishmania amazonensis & Maia et al. (2018) \\
\hline & Leishmania guyanensis & Maia et al. (2018) \\
\hline & Leishmania mexicana & Maia et al. (2018) \\
\hline & Leishmania panamensis & Maia et al. (2018) \\
\hline & Leishmania braziliensis & Schallig et al. (2007) \\
\hline & Leishmania infantum & Travi et al. (1994); \\
\hline & Toxoplasma gondii & Yai et al. (2003) \\
\hline & Trypanosoma cruzi & Galaviz-Silva et al. (2017) \\
\hline \multirow[t]{12}{*}{ Didelphis virginiana } & Helminths & \\
\hline & Spirometra mansonoides (Cestoda) & Corkum (1966) \\
\hline & Toxocara canis (Nematoda) & Blumenthal and Kirkland (1976) \\
\hline & Trichinella spiralis (Nematoda) & Leiby et al. (1988) \\
\hline & Angiostrongylus cantonensis (Nematoda) & Kim et al. (2002); Dalton et al. (2017) \\
\hline & Angiostrongylus costaricensis (Nematoda) & Miller et al. (2006) \\
\hline & Paragonimus kellicotti (Trematoda) & Blair et al. (1999) \\
\hline & Paragominus mexicanus (Trematoda) & Blair et al. (1999); López-Caballero et al. (2013) \\
\hline & Alaria marcianae (Trematoda) & Shoop and Corkum (1981) \\
\hline & Protozoa & \\
\hline & Toxoplasma gondii & Torres-Castro et al. (2016) \\
\hline & Trypanosoma cruzi & $\begin{array}{l}\text { Parada-López et al. (2013); Cantillo-Barraza et al. (2015); } \\
\text { Ruiz-Piña and Cruz-Reyes (2002) }\end{array}$ \\
\hline
\end{tabular}


life cycle comprised by two intermediate hosts (aquatic snails and crustaceans), and several mammal species as definitive hosts (Blair et al. 1999). In the Americas, opossums are among the definitive hosts for $P$. caliensis, $P$. kellicotti, and $P$. mexicanus, playing, along with intermediate hosts, a key role in the maintenance of these parasites in nature (Blair et al. 1999). Another parasite species associated with opossums is the trematode $A$. marcianae, reported on D. virginiana in Louisiana, USA (Shoop and Corkum 1981). The life cycle of this trematode involves two intermediate hosts (i.e., snails and amphibians) and a definitive host (i.e., canids, felids, or mustelids), with opossums being considered paratenic hosts (Möhl et al. 2009). Indeed, the consumption, or even manipulation (e.g., skinning, evisceration) of paratenic hosts have been implicated as a source of Alaria spp. infection to humans (Shoop and Corkum 1981; Möhl et al. 2009), highlighting the risks of the consumption of opossums by people. Finally, Gnathostoma spp. and Echinostoma spp. have been associated with opossums; however, although several species of these parasites are zoonotic, the ones reported (i.e., Gnathostoma turgidum and Echinostoma trivolvis) on these marsupials have not been proven to affect humans or domestic animals (Alden 1995; Maldonado and Lanfredi 2009; Torres-Montoya et al. 2018).

\section{Protozoa not vectored by arthropods}

Parasitic protozoa are particularly important due to their wide host range, which include humans, domestic and wild animals. Additionally, many of these parasites are responsible for important economic losses related to farm animals, and for causing disease in humans (Sahinduran 2012; Kaltungo and Musa 2013). In opossums, most studies on zoonotic protozoa infecting these marsupials described blood and gastrointestinal species of public health importance, such as Trypanosoma, Toxoplasma, Leishmania and Cryptosporidium spp. (Table 3). In this section we will focus on the gastrointestinal protozoa of public health concern (for vector-borne protozoa see sections 3.3 and 3.4).

Several studies have speculated about the role of opossums as reservoirs of T. gondii (Yai et al. 2003; Fornazari et al. 2011; Suzán and Ceballos 2005; Gennari et al. 2015). In fact, this protozoan has been molecularly and serologically detected in Didelphis spp. For example, T. gondii in these animals have been reported with seroprevalence of $37.3 \%(n=148 /$ 396 by indirect immunofluorescent antibody test - IFAT) in D. marsupialis; $5.55 \%$ ( $n=4 / 72$ by modified agglutination test - MAT) in D. albiventris; $10.34 \%$ ( $n=3 / 29$ by complement fixation test) in D. virginiana, and $12.5 \%(n=5 / 40$ by MAT) in D. aurita (Yai et al. 2003; Fornazari et al. 2011; Suzán and Ceballos 2005; Gennari et al. 2015). Additionally, DNA of this protozoan has been isolated from heart and brain tissues of $D$. aurita and D. virginiana, respectively (Pena et al. 2011; Torres-Castro et al. 2016). Finally, these animals are considered a food source in some regions, and the consumption of undercooked meat of these animals have been implicated as a potential risk for the transmission of T. gondii (Alvarado-Esquivel et al. 2016). However, their role in the transmission cycle of $T$. gondii remains unclear.

Other gastrointestinal protozoa (e.g., Cryptosporidium spp., and Giardia spp.) may be spread through contaminated feces of opossums in food and water (Oates et al. 2012). Studies on both the protozoa above affecting Didelphis spp. are scant, and most of them rely on the identification to the genus level (Zanette et al. 2008; Oates et al. 2012), which makes difficult the assessment of their zoonotic potential. Indeed, up to date only one experimental study performed in D. virginiana has demonstrated the infection of the zoonotic protozoan Cryptosporidium parvum in these animals, with four out of seven infected nursing opossums presenting mild clinical signs, such as diarrhea (Lindsay et al. 1988); however, factors such as age (youngsters, which may not present a completely developed immune system), high doses of C. parvum oocysts inoculated $\left(5 \times 100^{6}\right)$, and the lack of detection of natural infection of C. parvum in these marsupials make it unclear whether they are involved in the transmission of this parasite.

\section{Opossums as a source of parasitic infections to domestic animals}

The relationship between opossum and domestic animals has been recorded in several regions where these marsupials occur, with the direct and indirect contact among them, implicating in the transmission of parasites of animal health concern. For example, a high prevalence of A. caninum was detected in D. aurita in southeastern Brazil (Bezerra-Santos et al. 2020a), although the relative importance of opossums in transmitting this parasite to dogs and other susceptible hosts is unclear. Opossums have also been involved in the transmission of parasites of concern to farm animals. This is the case of D. virginiana, the definitive host of Sarcocystis neurona, a protozoan parasite known to cause severe and fatal neurologic disease in horses (Rossano et al. 2003). The above-mentioned examples are among the few studies investigating the importance of opossums in the epidemiology of parasitic diseases to domestic animals. Indeed, considering their circulation and contact with pets in urban environments, and with livestock in rural settings, these marsupials could be playing an underestimated role in the epidemiology of parasitic diseases affecting domestic animals and livestock. 


\section{Conclusions}

The ecological role of native species is essential for the equilibrium of an ecosystem. Anthropogenic activities and invasion of natural habitats of endemic wild species have negative consequences not only for the wildlife, but also for the health of humans and domestic animals, as many wildlife species are involved in the transmission of different zoonotic pathogens. Opossums are good examples of such animals, due to the direct (e.g., hunting, manipulation and consumption of their meat, illegal trade in local markets) and/or indirect contact (e.g., ectoparasites, contaminated food and water) of people and domestic animals with these marsupials. This situation brings important risks from a "One Health" point of view, as infectious agents may cause disease in some species (e.g., $R$. rickettsii in humans), but use other hosts only as reservoirs (e.g., $R$. rickettsii in opossums). Despite presenting substantial importance in a One Health context, knowledge on infectious agents of public and veterinary importance associated with opossums are still scant, advocating further research on the role these animals play in the epidemiology of such pathogens. In addition, the education of the population about the risks brought by the direct contact with such animals is pivotal to reduce the risks of sharing pathogens among marsupials, domestic animals, and humans.

Funding Open access funding provided by Università degli Studi di Bari Aldo Moro within the CRUI-CARE Agreement.

Open Access This article is licensed under a Creative Commons Attribution 4.0 International License, which permits use, sharing, adaptation, distribution and reproduction in any medium or format, as long as you give appropriate credit to the original author(s) and the source, provide a link to the Creative Commons licence, and indicate if changes were made. The images or other third party material in this article are included in the article's Creative Commons licence, unless indicated otherwise in a credit line to the material. If material is not included in the article's Creative Commons licence and your intended use is not permitted by statutory regulation or exceeds the permitted use, you will need to obtain permission directly from the copyright holder. To view a copy of this licence, visit http://creativecommons.org/licenses/by/4.0/.

\section{References}

Abbot P, Aviles AE, Eller L, Durden LA (2007) Mixed infections, cryptic diversity, and vector-borne pathogens: Evidence from Polygenis fleas and Bartonella species. Appl Environ Microbiol 73:60456052. https://doi.org/10.1128/AEM.00228-07

Abdullah S, Helps C, Tasker S, Newbury H, Wall R (2019) Pathogens in fleas collected from cats and dogs: Distribution and prevalence in the UK. Parasit Vectors 12:1-10. https://doi.org/10.1186/s13071019-3326-x

Abel IS, Marzagão G, Yoshinari NH, Schumaker TTS (2000) Borrelialike spirochetes recovered from ticks and small mammals collected in the Atlantic Forest reserve, Cotia county, state of São Paulo,
Brazil. Mem Inst Oswaldo Cruz 95:621-624. https://doi.org/10. 1590/S0074-02762000000500006

Abramowicz KF, Wekesa JW, Nwadike CN, Zambrano ML, Karpathy SE, Cecil D, Burns J, Hu R, Eremeeva ME (2012) Rickettsia felis in cat fleas, Ctenocephalides felis parasitizing opossums, San Bernardino County, California. Med Vet Entomol 26:458-462. https://doi.org/10.1111/j.1365-2915.2012.01017.x

Acevedo-Whitehouse K, Duffus ALJ (2009) Effects of environmental change on wildlife health. Philos Trans R Soc B Biol Sci 364: 3429-3438. https://doi.org/10.1098/rstb.2009.0128

Adler GH, Becerra MT, Travi BL (2003) Feeding success of Lutzomyia evansi (Diptera: Psychodidae) experimentally exposed to small mammal hosts in an endemic focus of Leishmania chagasi in northern Colombia. Biomedica 23:396-400. https://doi.org/10.7705/ biomedica.v23i4.1233

Aguirre AAR, Garcia MV, da Costa IN, Csordas BG, Rodrigues VS, Medeiros JF, Andreotti R (2018) New records of tick-associated spotted fever group Rickettsia in an Amazon-Savannah ecotone, Brazil. Ticks Tick Borne Dis 9:1038-1044. https://doi.org/10. 1016/j.ttbdis.2018.03.015

Alden KJ (1995) Helminths of the opossum, Didelphis virginiana, in Southern Illinois, with a compilation of all helminths reported from this host in North America. J Helminthol Soc Wash 62:197-208

Almeida AM, Brasil DP, Carvalho FG, Almeida CR (1987) Pesquisa de Yersinia pestis em roedores e outros pequenos mamiferos nos focos pestosos do nordeste do Brasil no periodo 1966 a 1982. Rev Saúde Pública 21:265-267

Almeida AM, Cintra Leal N, Carvalho FG, Dantas Sobrinho J, Almeida CR (1995) Plague surveillance in Brazil: 1983-1992. Rev Instit Med Trop São Paulo 37:511-516

Alvarado-Esquivel C, Salcedo-Jaquez M, Sanchez-Anguiano LF, Hernandez-Tinoco J, Rabago-Sanchez E, Beristain-Garcia I, Liesenfeld O, Estrada-Martinez S, Perez-Alamos AR, AlvaradoSoto E (2016) Association between Toxoplasma gondii exposure and heart disease: a case-control study. J Clin Med Res 8:402409. https://doi.org/10.14740/jocmr2525w

Amador-Alcalá S, Naranjo EJ, Jiménez-Ferrer G (2013) Wildlife predation on livestock and poultry: Implications for predator conservation in the rainforest of south-east Mexico. Oryx 47:243-250. https://doi. org/10.1017/S0030605311001359

Anderson JF, Magnarelli LA, Philip RN, Burgdorfer W (1986) Rickettsia rickettsii and Rickettsia montana from ixodid ticks in Connecticut. Am J Trop Med Hyg 32:187-191

Angelakis E, Mediannikov O, Parola P, Raoult D (2016) Rickettsia felis: The Complex Journey of an Emergent Human Pathogen. Trends Parasitol 32:554-564. https://doi.org/10.1016/j.pt.2016.04.009

Azad AF, Radulovic S, Higgins JA, Noden BH, Troyer JM (1997) Fleaborne rickettsioses: ecologic considerations. Emerg Infect Dis 3: 319-327. https://doi.org/10.3201/eid0303.970308

Barbieri JM, Rocha CMBMD, Bruhn FRP, Cardoso DL, Pinter A, Labruna MB (2015) Altitudinal assessment of Amblyomma aureolatum and Amblyomma ovale (Acari: Ixodidae), vectors of spotted fever group Rickettsiosis in the State of São Paulo, Brazil. J Med Entomol 52:1170-1174. https://doi.org/10.1093/jme/tjv073

Barbosa-Silva AN, Souza RCM, Diotauiti L, Aguiar LMA, da Câmara ACJ, Galvão LMC (2019) Synanthropic triatomines (Hemiptera: Reduviidae): infestation, colonization, and natural infection by trypanosomatids in the State of Rio Grande do Norte, Brazil. Rev Soc Bras Med Trop 52:1-8. https://doi.org/10.1590/0037-86820061-2019

Barratt J, Chan D, Sandaradura I, Malik R, Spielman D, Lee R, Marriott D, Harkness J, Ellis J, Stark D (2016) Angiostrongylus cantonensis: A review of its distribution, molecular biology and clinical significance as a human pathogen. Parasitol 143:1087-1118. https://doi. org/10.1017/S0031182016000652 
Barros FB, Azevedo PA (2014) Common opossum (Didelphis marsupialis Linnaeus, 1758): food and medicine for people in the Amazon. J Ethnobiol Ethnomed 10:65. https://doi.org/10.1186/ 1746-4269-10-65

Barros-Battesti DM, Yoshinari NH, Bonoldi VLN, Gomes AC (2000) Parasitism by Ixodes didelphidis and I. loricatus (Acari: Ixodidae) on small wild mammals from an Atlantic Forest in the State of Sao Paulo, Brazil. J Med Entomol 37:820-827. https://doi.org/10.1603/ 0022-2585-37.6.820

Beaucournu JC, Reynes JM, Vié JC (1998) Fleas in French Guiana (Insecta: Siphonaptera). J Med Entomol 35:3-10. https://doi.org/ 10.1093/jmedent $/ 35.1 .3$

Bermúdez SE, Castro AM, Esser H, Liefting Y, García G, Miranda RJ (2012) Ticks (Ixodida) on humans from central Panama, Panama (2010-2011). Exp Appl Acarol 58:81-88. https://doi.org/10.1007/ s10493-012-9564-7

Bermúdez SE, Castro AM, Trejos D, García GG, Gabster A, Miranda RJ, Zaldívar Y, Paternina LE (2016) Distribution of Spotted Fever Group Rickettsiae in hard ticks (Ixodida: Ixodidae) from Panamanian urban and rural environments (2007-2013). Ecohealth 13:274-284. https://doi.org/10.1007/s10393-016-1118-8

Bezerra-Santos MA, Furtado LFV, Rabelo ÉML, Nogueira BCF, Yamatogi RS, Campos AK (2020a) High prevalence of Ancylostoma caninum infection in black-eared opossums (Didelphis aurita) in an urban environment. Parasitol Res 119: 2343-2346. https://doi.org/10.1007/s00436-020-06708-1

Bezerra-Santos MA, Nogueira BCF, Yamatogi RS, Ramos RAN, Galhardo JA, Campos AK (2020b) Ticks, fleas and endosymbionts in the ectoparasite fauna of the black-eared opossum Dipelphis aurita in Brazil. Exp Appl Acarol 80:329-338. https://doi.org/10. 1007/s10493-020-00468-4

Bezerra-Santos MA, Nogueira BCF, Yamatogi RS, Campos AK (2020c) Molecular detection of Toxoplasma gondii in opossums from Southeastern, Brazil. J Parasitic Dis 44:661-665. https://doi.org/ 10.1007/s12639-020-01243-3

Bezerra-Santos MA, Mendoza-Roldan JA, Thompson RCA, DantasTorres F, Otranto D (2021a) Illegal wildlife trade: a gateway to zoonotic infectious diseases. Trends Parasitol 37:181-184. https:// doi.org/10.1016/j.pt.2020.12.005

Bezerra-Santos MA, Mendoza-Roldan JA, Thompson RCA, DantasTorres F, Otranto D (2021b) Legal versus Illegal Wildlife Trade: Zoonotic Disease Risks. Trends Parasitol. https://doi.org/10.1016/j. pt.2021.02.0032021.02.003

Binetruy F, Chevillon C, de Thoisy B, Garnier S, Duron O (2019) Survey of ticks in French Guiana. Ticks Tick Borne Dis 10:77-85. https:// doi.org/10.1016/j.ttbdis.2018.09.003

Bitencourth K, Amorim M, de Oliveira SV, Caetano RL, Voloch CM, Gazêta GS (2017) Amblyomma sculptum: genetic diversity and rickettsias in the Brazilian Cerrado biome. Med Vet Entomol 31:427437. https://doi.org/10.1111/mve.12249

Blair D, Xu ZB, Agatsuma T (1999) Paragonimiasis and the genus Paragonimus. Adv Parasitol 42:113-222. https://doi.org/10.1016/ s0065-308x(08)60149-9

Blumenthal EM, Kirkland JR GL (1976) The biology of the opossum, Didelphis virginiana in southcentral Pennsylvania. In Proceedings of the Pennsylvania Academy of Science 50:81-85. Pennsylvania Academy of Science.

Boostrom A, Beier MS, Macaluso JA, Macaluso KR, Sprenger D, Hayes J, Radulovic S, Azad AF (2002) Geographic Association of Rickettsia felis-Infected Opossums with Human Murine Typhus, Texas. Emerg Infect Dis 8:549-554. https://doi.org/10.3201/ Feid0806.010350

Borsoi ABP, Bitencourth K, de Oliveira SV, Amorin M, Gazêta G (2019) Human parasitism by Amblyomma parkeri ticks infected with Candidatus Rickettsia paranaensis, Brazil. Emerg Infect Dis 25: 2339-2341. https://doi.org/10.3201/eid2512.1909819-0988
Brouqui P, Stein A, Dupont HT, Gallian P, Badiaga S, Rolain JM, Mege JL, La Scola B, Berbis P, Raoult D (2005) Ectoparasitism and vector-borne diseases in 930 homeless people from Marseilles. Medicine (Baltimore) 84:61-68. https://doi.org/10.1097/01.md. $0000152373.07500 .6 \mathrm{e}$

Brown LD, Macaluso KR (2016) Rickettsia felis, an Emerging FleaBorne Rickettsiosis. Curr Trop Med Rep 3:27-39. https://oi.org/ 10.1007/s40475-016-0070-6

Cáceres NC, Monteiro-Filho ELA (2001) Food habits, home range and activity of Didelphis aurita (Mammalia, Marsupialia) in a forest fragment of southern Brazil. Stud Neotrop Fauna Environ 36:8592. https://doi.org/10.1076/snfe.36.2.85.2138

Cantillo-Barraza O, Garcés E, Gómez-Palacio A, Cortés LA, Pereira A, Marcet PL, Jansen AM, Triana-Chávez O (2015) Ecoepidemiological study of an endemic Chagas disease region in northern Colombia reveals the importance of Triatoma maculata (Hemiptera: Reduviidae), dogs and Didelphis marsupialis in Trypanosoma cruzi maintenance. Parasit Vectors 8:1-10. https:// doi.org/10.1186/s13071-015-1100-2

Canto-Osorio JM, Cuxim-Koyoc A, Ruiz-Piña HA, Morales-Malacara JB, Reyes-Novelo E (2020) Ectoparasites of Didelphis virginiana from Yucatan, Mexico. J Med Entomol 1-9. https://doi.org/10. 1093/jme/tjaa106

Cantor M, Ferreira LA, Silva WR, Setz EZF (2010) Potencial dispersão de sementes por Didelphis albiventris (Marsupialia, Didelphidae) em ambiente altamente perturbado. Biota Neotrop 10:45-51. https://doi.org/10.1590/S1676-06032010000200004

Carranza-Tamayo CO, Werneck GL, Romero GAS (2016) Are opossums a relevant factor associated with asymptomatic Leishmania infection in the outskirts of the largest Brazilian cities? Braz J Infect Dis 20: 119-126. https://doi.org/10.1016/j.bjid.2015.11.013

Carreira JCA, Da Silva AVMH, De Pita PD, Brazil RP (2012) Natural infection of Didelphis aurita (Mammalia: Marsupialia) with Leishmania infantum in Brazil. Parasit Vectors 5:2-6. https://doi. org/10.1186/1756-3305-5-111

Carvalho LA, Maya L, Armua-Fernandez MT, Félix ML, Bazzano V, Barbieri AM, González EM, Lado P, Colina R, Díaz P, Labruna MB, Nava S, Venzal JM (2020) Borrelia burgdorferi sensu lato infecting Ixodes auritulus ticks in Uruguay. Exp Appl Acarol 80: 109-125. https://doi.org/10.1007/s10493-019-00435-8

Castaño Zubieta R, Ruiz M, Morici G, Lovera R, Fernández MS, Caracostantogolo J, Cavia R (2014) First report of Trichinella spiralis from the white-eared (Didelphis albiventris) and the thicktailed opossum (Lutreolina crassicaudata) in central Argentina. Helminthol 51:198-202. https://doi.org/10.2478/s11687-014-02294

Castellaw AH, Chenney EF, Varela-Stokes AS (2011) Tick-borne disease agents in various wildlife from Mississippi. Vector-Borne Zoonotic Dis 11:439-442. https://doi.org/10.1089/vbz.2009.0221

Childs JE, Paddock CD (2003) The ascendancy of Amblyomma americanum as a vector of pathogens affecting humans in the United States. Annu Rev Entomol 48:307-337. https://doi.org/10. 1146/annurev.ento.48.091801.112728

Chomel BB, Belotto A, Meslin FX (2007) Wildlife, exotic pets, and emerging zoonoses. Emerg Infect Dis 13:6-11. https://doi.org/10. 3201/eid1301.060480

Christou C, Psaroulaki A, Antoniou M, Toumazos P, Ioannou I, Mazeris A, Chochlakis D, Tselentis Y (2010) Rickettsia typhi and Rickettsia felis in Xenopsylla cheopis and Leptopsylla segnis parasitizing rats in Cyprus. Am J Trop Med Hyg 83:1301-1304. https://doi.org/10. 4269/ajtmh.2010.10-0118

Coelho PMZ, Dias M, Mayrink W, Magalhães P, Mello MN, Costa CA (1979) Wild reservoirs of Schistosoma mansoni from Caratinga, an endemic schistosomiasis area of Minas Gerais State, Brazil. Am J Trop Med Hyg 28:163-164. https://doi.org/10.4269/ajtmh.1979.28. 163 
Corkum KC (1966) Sparganosis in some vertebrates of Louisiana and observations on a human infection. J Parasitol 52:444. https://doi. org/10.2307/3276305

Costa FB, da Costa AP, Moraes-Filho J, Martins TF, Soares HS, Ramirez DG, Dias RA, Labruna MB (2017) Rickettsia amblyommatis infecting ticks and exposure of domestic dogs to Rickettsia spp. in an Amazon-Cerrado transition region of northeastern Brazil. PLoS One 12:1-17. https://doi.org/10.1371/journal.pone.0179163

Cruz-Salazar B, Ruiz-Montoya L (2020) Population viability analysis of common marsupials, Didelphis marsupialis and Didelphis virginiana, in a scenario of constant loss of native vegetation. Mammalia:1-8. https://doi.org/10.1515/mammalia-2019-0130

da Silva MRL, Fornazari F, Demoner LC, Teixeira CR, Langoni H, O'Dwyer LH (2017) Didelphis albiventris naturally infected with Hepatozoon canis in southeastern Brazil. Ticks Tick Borne Dis 8: 878-881. https://doi.org/10.1016/j.ttbdis.2017.07.005

Dalton MF, Fenton H, Cleveland CA, Elsmo EJ, Yabsley MJ (2017) Eosinophilic meningoencephalitis associated with rat lungworm (Angiostrongylus cantonensis) migration in two nine-banded armadillos (Dasypus novemcinctus) and an opossum (Didelphis virginiana) in the southeastern United States. Int J Parasitol Parasit Wildl 6:131-134. https://doi.org/10.1016/j.ijppaw.2017.05.004

Dantas-Torres F (2015) Climate change, biodiversity, ticks and tickborne diseases: The butterfly effect. Int J Parasitol Parasit Wildl 4: 452-461. https://doi.org/10.1016/j.ijppaw.2015.07.001

Dantas-Torres F, Figueredo LA, Brandão-Filho SP (2006) Rhipicephalus sanguineus (Acari: Ixodidae), the brown dog tick, parasitizing humans in Brazil. Rev Soc Bras Med Trop 39:64-67. https://doi. org/10.1590/S0037-86822006000100012

Dantas-Torres F, Siqueira DB, Rameh-De-Albuquerque LC, Da Silva E, Souza D, Zanotti AP, Ferreira DRA, Martins TF, De Senna MB, Wagner PGC, Da Silva MA, Marvulo MFV, Labruna MB (2010) Ticks infesting wildlife species in Northeastern Brazil with new host and locality records. J Med Entomol 47:1243-1246. https://doi.org/ $10.1603 / \mathrm{me} 10156$

Dantas-Torres F, Chomel BB, Otranto D (2012a) Ticks and tick-borne diseases: A One Health perspective. Trends Parasitol 28:437-446. https://doi.org/10.1016/j.pt.2012.07.003

Dantas-Torres F, Aléssio FM, Siqueira DB, Mauffrey J, Marvulo MFV, Martins TF, Moraes-Filho J, Camargo MCGO, D'Auria SRN, Labruna MB, Silva JCR (2012b) Exposure of small mammals to ticks and rickettsiae in Atlantic Forest patches in the metropolitan area of Recife, North-eastern Brazil. Parasitol 139:83-91. https:// doi.org/10.1017/s0031182011001740

de Lemos ER, Machado RD, Coura JR, Guimarães MA, Freire NM (1996) Infestation by ticks and detection of antibodies to spotted fever group rickettsiae in wild animals captured in the state of São Paulo, Brazil. A preliminary report. Mem Inst Oswaldo Cruz 91: 701-702. https://doi.org/10.1590/s0074-02761996000600008

de Moraes LB, Paolinetti Bossi DE, Linhares AX (2003) Siphonaptera parasites of wild rodents and marsupials trapped in three mountain ranges of the Atlantic Forest in Southeastern Brazil. Mem Inst Oswaldo Cruz 98:1071-1076. https://doi.org/10.1590/s007402762003000800017

de Noya BA, González ON (2015) An ecological overview on the factors that drives to Trypanosoma cruzi oral transmission. Acta Trop 151: 94-102. https://doi.org/10.1016/j.actatropica.2015.06.004

de Oliveira Carneiro I, de Jesus SN, Silva NS, Lima PC, Meyer R, Netto EM, Franke CR (2019) Knowledge, practice and perception of human-marsupial interactions in health promotion. J Infect Dev Ctries 13:342-347. https://doi.org/10.3855/jidc.10177

Dean KR, Krauer F, Walløe L, Lingjærde OC, Bramanti B, Stenseth NC, Schmid BV (2018) Human ectoparasites and the spread of plague in Europe during the Second Pandemic. Proc Natl Acad Sci U S A 115: 1304-1309. https://doi.org/10.1073/pnas.1715640115
Demeure C, Dussurget O, Fiol GM, Le Guern AS, Savin C, PizarroCerdá J (2019) Yersinia pestis and plague: an updated view on evolution, virulence determinants, immune subversion, vaccination and diagnostics. Microbes Infect 21:202-212. https://doi.org/10. 1016/j.micinf.2019.06.007

Diaz JH, Warren RJ, Oster MJ (2020) The disease ecology, epidemiology, clinical manifestations, and management of trichinellosis linked to consumption of wild animal meat. Wilderness Environ Med 31: 235-244. https://doi.org/10.1016/j.wem.2019.12.003

Dolz G, Castro R, Jiménez-Rocha AE, Retamosa M, Alberti A (2019) Strain diversity of Rickettsia amblyommatis in ticks infesting birds in the North Huetar conservation area of Costa Rica. Ticks Tick Borne Dis 10:1109-1112. https://doi.org/10.1016/j.ttbdis.2019.06. 007

Domínguez L, Miranda RJ, Torres S, Moreno R, Ortega J, Bermúdez SE (2019) Hard tick (Acari: Ixodidae) survey of Oleoducto trail, Soberania National Park, Panama. Ticks Tick Borne Dis 10:830 837. https://doi.org/10.1016/j.ttbdis.2019.04.001

Drozino RN, Otomura FH, Gazarini J, Gomes ML, Toledo MJO (2019) Trypanosoma found in synanthropic mammals from urban forests of Paraná, Southern Brazil. Vector-Borne Zoonotic Dis 19:828-834. https://doi.org/10.1089/vbz.2018.2433

Durden LA, Richardson DJ (2013) Ectoparasites of the Virginia opossum (Didelphis virginiana), raccoon (Procyon lotor), and striped skunk (Mephitis mephitis) from Keith County, Nebraska. Trans Nebraska Acad Sci 33:21-24

Durden LA, Wilson N (2016) Ectoparasitic and phoretic arthropods of Virginia Opossums (Didelphis virginiana) in Central Tennessee. Published by: Allen Press on behalf of The American Society of Parasitologists Stable URL: http://www.jstor.org/stable/3282847 Accessed: 15-03-2016. 76:581-583

Ehlers J, Krüger A, Rakotondranary SJ, Ratovonamana RY, Poppert S, Ganzhorn JU, Tappe D (2020) Molecular detection of Rickettsia spp., Borrelia spp., Bartonella spp. and Yersinia pestis in ectoparasites of endemic and domestic animals in southwest Madagascar. Acta Trop 205:105339. https://doi.org/10.1016/j.actatropica.2020. 105339

Eisen RJ, Eisen L (2018) The blacklegged tick, Ixodes scapularis: an increasing Public Health concern. Trends Parasitol 34:295-309. https://doi.org/10.1016/j.pt.2017.12.006

Eremeeva ME, Warashina WR, Sturgeon MM, Buchholz AE, Olmsted GK, Park SY, Effler PV, Karpathy SE (2008) Rickettsia typhi and R. felis in rat fleas (Xenopsylla cheopis), Oahu, Hawaii. Emerg Infect Dis 14:1613-1615. https://doi.org/10.3201/eid1410.080571

Eremeeva ME, Karpathy SE, Krueger L, Hayes EK, Williams AM, Zaldivar Y, Bennett S, Cummings R, Tilzer A, Velten RK, Kerr N, Dasch GA, Hu R (2012) Two pathogens and one disease: detection and identification of flea-borne rickettsiae in areas endemic for Murine Typhus in California. J Med Entomol 49:1485-1494. https://doi.org/10.1603/me11291

Faria MB, de Melo F (2017) Didelphis imperfecta, Didelphimorfia, Didelphidae (Mondolfi \& Pérez-Hernández, 1984): a new record in the Brazilian Amazon. Bol da Soc Bras Mastozool 79:44-46

Fish D, Dowler RC (1989) Host associations of ticks (Acari: Ixodidae) parasitizing medium-sized mammals in a Lyme disease endemic area of southern New York. J Med Entomol 26:200-209. https:// doi.org/10.1093/jmedent/26.3.200

Flores FS, Muñoz-Leal S, Diaz A, Labruna MB (2018) Wild birds as host of Borrelia burgdorferi sensu lato in northwestern Argentina. Ticks Tick Borne Dis 9:1586-1589. https://doi.org/10.1016/j.ttbdis.2018. 08.005

Fontalvo MC, Favacho ARM, Araujo AC, Santos NM, Oliveira GMB, Aguiar DM, Lemos ERS, Horta MC (2017) Bartonella species pathogenic for humans infect pets, free-ranging wild mammals and their ectoparasites in the Caatinga biome, Northeastern Brazil: a 
serological and molecular study. Braz J Infect Dis 21:290-296. https://doi.org/10.1016/j.bjid.2017.02.002

Fornazari F, Teixeira CR, da Silva RC, Leiva M, de Almeida SC, Langoni H (2011) Prevalence of antibodies against Toxoplasma gondii among brazilian white-eared opossums (Didelphis albiventris). Vet Parasitol 179:238-241. https://doi.org/10.1016/j. vetpar.2011.02.005

Gabriel MW, Henn J, Foley JE, Brown RN, Kasten RW, Foley P, Chomel BB (2009) Zoonotic Bartonella species in fleas collected on gray foxes (Urocyon cinereoargenteus). Vector-Borne Zoonotic Dis 9:597-602. https://doi.org/10.1089/vbz.2008.0134

Galaviz-Silva L, Mercado-Hernández R, Zárate-Ramos JJ, Molina-Garza ZJ (2017) Prevalence of Trypanosoma cruzi infection in dogs and small mammals in Nuevo León, Mexico. Rev Argent Microbiol 49: 216-223. https://doi.org/10.1016/j.ram.2016.11.006

Garcia MV, Matias J, Aguirre ADAR, Csordas BG, Szabó MPJ, Andreotti R (2015) Successful feeding of Amblyomma coelebs (Acari: Ixodidae) nymphs on humans in Brazil: skin reactions to parasitism. J Med Entomol 52:117-119. https://doi.org/10.1093/ jme/tju060

Gardner AL (2008) Mammals of South America, Volume 1. University of Chicago Press

Gennari SL, Ogrzewalska MH, Soares HS, Saraiva DG, Pinter A, NieriBastos FA, Labruna MB, Szabó MPJ, Dubey JP (2015) Toxoplasma gondii antibodies in wild rodents and marsupials from the Atlantic Forest, state of São Paulo, Brazil. Braz J Vet Parasitol 24:379-382. https://doi.org/10.1590/S1984-29612015045

Goddard J (1989) Focus of human parasitism by the brown dog tick, Rhipicephalus sanguineus (Acari: Ixodidae). J Med Entomol 26: 628-631. https://doi.org/10.1093/jmedent/26.6.628

Gruhn KD, Ogrzewalska M, Rozental T, Farikoski IO, Blanco C, Freitas LS, de Lemos ERS, Ribeiro VMF (2019) Evaluation of rickettsial infection in free-range capybaras (Hydrochoerus hydrochaeris Linnaeus, 1766) (Rodentia: Caviidae) and ticks (Acari: Ixodidae) in the Western Amazon, Brazil. Ticks Tick Borne Dis 10:981986. https://doi.org/10.1016/j.ttbdis.2019.04.007

Guglielmone AA, Beati L, Barros-Battesti DM, Labruna MB, Nava S, Venzal JM, Mangold AJ, Szabó MPJ, Martins JR, González-Acuña D, Estrada-Peña A (2006) Ticks (Ixodidae) on humans in South America. Exp Appl Acarol 40:83-100. https://doi.org/10.1007/ s10493-006-9027-0

Guimarães-E-Silva AS, De Oliveira SS, Da Silva RCR, Pinheiro VCS, Rebêlo JMM, Melo MN (2017) Leishmania infection and blood food sources of phlebotomines in an area of Brazil endemic for visceral and tegumentary leishmaniasis. PLoS One 12:1-19. https://doi.org/10.1371/journal.pone.0179052

Gumier-Costa F, Sperber CF (2009) Roadkills of vertebrates in carajas national forest, Para, Brazil. Acta Amaz 39:459-466. https://doi.org/ 10.1590/s0044-59672009000200027

Haddad NM, Brudvig LA, Clobert J, Davies KF, Gonzalez A, Holt RD, Lovejoy TE, Sexton JO, Austin MP, Collins CD, Cook WM, Damschen EI, Ewers RM, Foster BL, Jenkins CN, King AJ, Laurance WF, Levey DJ, Margules CR, Melbourne BA, Nicholls AO, Orrock JL, Song DX, Townshend JR (2015) Habitat fragmentation and its lasting impact on Earth's ecosystems. Sci Adv 1:1-10. https://doi.org/10.1126/sciadv.1500052

Hall JE, Amrine JW, Gais RD, Kolanko VP, Hagenbuch BE, Gerencser VF, Clark SM (1991) Parasitization of humans in West Virginia by Ixodes cookei (Acari: Ixodidae), a potential vector of Lyme borreliosis. J Med Entomol 28:186-189. https://doi.org/10.1093/ jmedent/28.1.186

Hanincová K, Kurtenbach K, Diuk-Wasser M, Brei B, Fish D (2006) Epidemic spread of Lyme borreliosis, northeastern United States. Emerg Infect Dis 12:604-611. https://doi.org/10.3201/eid1204. 051016
Hecht JA, Allerdice MEJ, Dykstra EA, Mastel L, Eisen RJ, Johnson TL, Gaff HD, Varela-Stokes AS, Goddard J, Pagac BB, Paddock CD, Karpathy SE (2019) Multistate survey of American dog ticks (Dermacentor variabilis) for Rickettsia species. Vector-Borne Zoonotic Dis 19:652-657. https://doi.org/10.1089/vbz.2018.2415

Hinnebusch BJ, Bland DM, Bosio CF, Jarrett CO (2017) Comparative ability of Oropsylla montana and Xenopsylla cheopis fleas to transmit Yersinia pestis by two different mechanisms. PLoS Negl Trop Dis 11:1-15. https://doi.org/10.1371/journal.pntd.0005276

Horta MC, Pinter A, Schumaker TTS, Labruna MB (2006) Natural infection, transovarial transmission, and transstadial survival of Rickettsia bellii in the tick Ixodes loricatus (Acari: Ixodidae) from Brazil. Ann N Y Acad Sci 1078:285-290. https://doi.org/10.1196/ annals. 1374.053

Horta MC, Labruna MB, Pinter A, Linardi PM, Schumaker TTS (2007) Rickettsia infection in five areas of the state of São Paulo, Brazil. Mem Inst Oswaldo Cruz 102:793-801. https://doi.org/10.1590/ S0074-02762007000700003

Horta MC, Moraes-Filho J, Casagrande RA, Saito TB, Rosa SC, Ogrzewalska M, Matushima ER, Labruna MB (2009) Experimental infection of opossums Didelphis aurita by Rickettsia rickettsii and evaluation of the transmission of the infection to ticks Amblyomma cajennense. Vector-Borne Zoonotic Dis 9:109-117. https://doi.org/10.1089/vbz.2008.0114

Horta MC, Sabatini GS, Moraes-Filho J, Maria O, Canal RB, Pacheco RC, Martins TF, Matushima ER, Labruna MB (2010) Experimental infection of the opossum Didelphis aurita by Rickettsia felis, Rickettsia bellii, and Rickettsia parkeri and evaluation of the transmission of the infection to ticks Amblyomma cajennense and Amblyomma dubitatum. Vector-Borne Zoonotic Dis 10:959-967. https://doi.org/10.1089/vbz.2009.0149

Humberg RMP, Oshiro ET, Pires E, Cruz MS, Ribolla PEM, Alonso DP, Ferreira AMT, Bonamigo RA, Tasso N, de Oliveira AG (2012) Short report: Leishmania chagasi in opossums (Didelphis albiventris) in an urban area endemic for visceral leishmaniasis, Campo Grande, Mato Grosso do Sul, Brazil. Am J Trop Med Hyg 87:470-472. https://doi.org/10.4269/ajtmh.2012.11-0534

Jansen AM (2002) Marsupiais Didelfídeos : gambás e cuícas. In: Andrade A, Pinto SC, Oliveira R (eds) Animais de Laboratório: criação e experimentação. FIOCRUZ, Rio de Janeiro, p 388

Jansen AM, Roque ALR (2010) Domestic and wild mammalian reservoirs. Am Trypanos:249-276. https://doi.org/10.1016/B978-0-12384876-5.00011-3

Jansen AM, Xavier SCC, Roque ALR (2015) The multiple and complex and changeable scenarios of the Trypanosoma cruzi transmission cycle in the sylvatic environment. Acta Trop 151:1-15. https://doi. org/10.1016/j.actatropica.2015.07.018

Jansen AM, Xavier SCC, Roque ALR (2017) Ecological aspects of Trypanosoma cruzi: wild hosts and reservoirs. Second Edi, Elsevier Inc

Jiang J, Maina AN, Knobel DL, Cleaveland S, Laudisoit A, Wamburu K, Ogola E, Parola P, Breiman RF, Njenga MK, Richards AL (2013) Molecular detection of Rickettsia felis and Candidatus Rickettsia asemboensis in fleas from human habitats, Asembo, Kenya. Vector-Borne Zoonotic Dis 13:550-558. https://doi.org/10.1089/ vbz.2012.1123

Jiménez FA, Catzeflis F, Gardner SL (2011) Structure of parasite component communities of didelphid marsupials: insights from a comparative study. J Parasitol 97:779-787. https://doi.org/10.1645/GE2711.1

Júnior PCB, Guimarães DA, Le Pendu Y (2010) Non-legalized commerce in game meat in the Brazilian Amazon: A case study. Rev Biol Trop 58:1079-1088. https://doi.org/10.15517/rbt.v58i2.5264

Kaltungo BY, Musa IW (2013) A review of some protozoan parasites causing infertility in farm animals. ISRN Trop Med 2013:1-6. https://doi.org/10.1155/2013/782609 
Karpathy SE, Hayes EK, Williams AM, Kerr N, Moore W, Eremeeva ME (2009) Detection of Rickettsia felis and Rickettsia typhi in an area of California endemic for murine typhus. Clin Microbiol Infect 15:218-2019. https://doi.org/10.1111/j.1469-0691.2008.02140.x

Kawazoe U, Souza Dias LC, Piza JT (1978) Infecção natural de pequenos mamíferos por Schistosoma mansoni, na represa de Americana (São Paulo, Brasil). Rev Saude Publica 12:200-208. https://doi.org/10. 1590/s0034-89101978000200012

Kim DY, Stewart TB, Bauer RW, Mitchell M (2002) Parastrongylus (=Angiostrongylus) cantonensis now endemic in Louisiana Wildlife. J Parasitol 88:1024. https://doi.org/10.2307/3285552

Kollars TM (1993) Ticks (Acari: Ixodidae) infesting medium-sized wild mammals in southwestern Tennessee. J Med Entomol 30:896-900. https://doi.org/10.1093/jmedent/30.5.896

Krause WJ, Krause WA (2006) The opossum: its amazing story. Department of Pathology and Anatomical Sciences. University of Missouri, Columbia, School of Medicine

Krawczak FS, Martins TF, Oliveira CS, Binder LC, Costa FB, Nunes PH, Gregori F, Labruna MB (2015) Amblyomma yucumense n. sp. (Acari: Ixodidae), a parasite of wild mammals in Southern Brazil. J Med Entomol 52:28-37. https://doi.org/10.1093/jme/tju007

Kumsa B, Parola P, Raoult D, Socolovschi C (2014) Molecular detection of Rickettsia felis and Bartonella henselae in dog and cat fleas in Central Oromia, Ethiopia. Am J Trop Med Hyg 90:457-462. https:// doi.org/10.4269/ajtmh.13-0010

Kuntz RE, Myers BJ, Cheever AW (1971) Schistosoma haematobium infection in the opossum (Didelphis marsupialis): involvement of the urogenital system. Bull World Health Organ 45:21-25

Kuntz RE, Myers BJ, Moore JA, Huang TC (1975) Parasitological aspects of Schistosoma haematobium (Iran) infection in the American opossum (Didelphis marsupialis L.). Int J Parasitol 5:21-26. https:// doi.org/10.1016/0020-7519(75)90092-2

Labruna MB, Camargo LMA, Terrassini FA, Ferreira F, Schumaker TTS, Camargo EP (2004) Ticks (Acari: Ixodidae) from the state of Rondonia, western Amazon, Brazil. Syst Appl Acarol 10:17. https://doi.org/10.11158/saa.10.1.4

Labruna MB, Cabrera RR, Pinter A (2009) Life cycle of Ixodes luciae (Acari: Ixodidae) in the laboratory. Parasitol Res 105:1749-1753. https://doi.org/10.1007/s00436-009-1621-8

Labruna MB, Marcili A, Ogrzewalska M, Barros-Battesti DM, DantasTorres F, Fernandes AA, Leite RC, Venzal JM (2014) New records and human parasitism by Ornithodoros mimon (Acari: Argasidae) in Brazil. J Med Entomol 51:283-287. https://doi.org/10.1603/ me13062

Lamattina D, Nava S (2016) Ticks infesting humans in Northern Misiones, Argentina. Med 76:89-92

Lamattina D, Tarragona EL, Nava S (2018a) Molecular detection of the human pathogen Rickettsia parkeri strain Atlantic rainforest in Amblyomma ovale ticks in Argentina. Ticks Tick Borne Dis 9: 1261-1263. https://doi.org/10.1016/j.ttbdis.2018.05.007

Lamattina D, Venzal JM, Costa SA, Arrabal JP, Flores S, Berrozpe PE, González-Acuña D, Guglielmone AA, Nava S (2018b) Ecological characterization of a tick community across a landscape gradient exhibiting differential anthropogenic disturbance in the Atlantic Forest ecoregion in Argentina. Med Vet Entomol 32:271-281. https://doi.org/10.1111/mve.12295

Lareschi M, Venzal JM, Arzua M, González E (2006) Fleas of small mammals in Uruguay, with new host and distribution records. Comp Parasitol 73:263-268. https://doi.org/10.1654/4193.1

Lavender DR, Oliver JH (1996) Ticks (Acari: Ixodidae) in Bulloch County, Georgia. J Med Entomol 33:224-231. https://doi.org/10. 1093/jmedent/33.2.224

Legey AP, Pinho AP, Xavier SCC, Marchevsky R, Carreira JC, Leon LL, Jansen AM (2003) Trypanosoma cruzi in marsupial didelphids (Philander frenata and Didelhis marsupialis): differences in the humoral immune response in natural and experimental infections.
Rev Soc Bras Med Trop 36:241-244. https://doi.org/10.1590/ S0037-86822003000200008

Leiby DA, Schad GA, Duffy CH, Murrell KD (1988) Trichinella spiralis in an agricultural ecosystem. III. Epidemiological investigations of Trichinella spiralis in resident wild and feral animals. J Wildl Dis 24:606-609. https://doi.org/10.7589/0090-3558-24.4.606

Levin ML, Zemtsova GE, Killmaster LF, Snellgrove A, Schumacher LBM (2017) Vector competence of Amblyomma americanum (Acari: Ixodidae) for Rickettsia rickettsii. Ticks Tick Borne Dis 8: 615-622. https://doi.org/10.1016/j.ttbdis.2017.04.006

Lima MM, Sarquis O, de Oliveira TG, Gomes TF, Coutinho C, DaflonTeixeira NF, Toma HK, Britto C, Teixeira BR, D'Andrea PS, Jansen AM, Bóia MN, Carvalho-Costa FA (2012) Investigation of Chagas disease in four periurban areas in northeastern Brazil: Epidemiologic survey in man, vectors, non-human hosts and reservoirs. Trans $\mathrm{R}$ Soc Trop Med Hyg 106:143-149. https://doi.org/10.1016/j.trstmh. 2011.10.013

Lima BS, Dantas-Torres F, de Carvalho MR, Marinho-Junior JF, de Almeida EL, Brito MEF, Gomes F, Brandão-Filho SP (2013) Small mammals as hosts of Leishmania spp. in a highly endemic area for zoonotic leishmaniasis in north-eastern Brazil. Trans R Soc Trop Med Hyg 107:592-597. https://doi.org/10.1093/trstmh/trt062

Lindsay DS, Hendrix CM, Blagburn BL (1988) Experimental Cryptosporidium parvum infections in opossums (Didelphis virginiana). J Wildl Dis 24:157-159. https://doi.org/10.7589/00903558-24.1.157

Lopes MG, Muñoz-Leal S, de Lima JTR, Fournier GFSR, Acosta ICL, Martins TF, Ramirez DG, Gennari SM, Labruna MB (2018) Ticks, rickettsial and erlichial infection in small mammals from Atlantic forest remnants in northeastern Brazil. Int J Parasitol Parasit Wild1 7: 380-385. https://doi.org/10.1016/j.ijppaw.2018.10.001

López-Caballero J, Oceguera-Figueroa A, León-Règagnon V (2013) Detection of multiple species of human Paragonimus from Mexico using morphological data and molecular barcodes. Mol Ecol Resour 13:1125-1136. https://doi.org/10.1111/1755-0998. 12093

López-Pérez AM, Osikowicz L, Bai Y, Montenieri J, Rubio A, Moreno K, Gage K, Suzán G, Kosoy M (2017) Prevalence and phylogenetic analysis of Bartonella species of wild carnivores and their fleas in Northwestern Mexico. Ecohealth 14:116-129. https://doi.org/10. 1007/s10393-017-1216-2

Luz HR, da Costa Neto SF, Weksler M, Gentile R, Faccini JLH (2018) Ticks parasitizing wild mammals in Atlantic forest areas in the state of Rio de Janeiro, Brazil. Braz J Vet Parasitol 27:409-414. https:// doi.org/10.1590/s1984-296120180027

Maggi RG, Toliver M, Richardson T, Mather T, Breitschwerdt EB (2019) Regional prevalences of Borrelia burgdorferi, Borrelia bissettiae, and Bartonella henselae in Ixodes affinis, Ixodes pacificus and Ixodes scapularis in the USA. Ticks Tick Borne Dis 10:360-364. https://doi.org/10.1016/j.ttbdis.2018.11.015

Maia C, Dantas-Torres F, Campino L (2018) Parasite Biology: The Reservoir Hosts. In: Bruschi F, Gradoni L (eds) The Leishmaniases: Old Neglected Tropical Diseases. Springer, Cham. https://doi.org/10.1007/978-3-319-72386-0_4

Maina AN, Fogarty C, Krueger L, Macaluso KR, Odhiambo A, Nguyen K, Farris CM, Luce-Fedrow A, Bennett S, Jiang J, Sun S, Cummings RF, Richards AL (2016) Rickettsial infections among Ctenocephalides felis and host animals during a flea-borne rickettsioses outbreak in Orange County, California. PLoS One 11: 1-13. https://doi.org/10.1371/journal.pone.0160604

Maldonado A, Lanfredi RM (2009) Echinostomes in the wild. In: Toledo R, Fried B (eds) The Biology of Echinostomes. Springer, New York, NY. https://doi.org/10.1007/978-0-387-09577-6_6

Marques S, Col RD, De Júnior MOM, Gonçalves EFB, Pinter A, Labruna MB (2006) Parasitismo de Amblyomma fuscum (Acari: Ixodidae) 
em humanos. Cienc Rural 36:1328-1330. https://doi.org/10.1590/ S0103-84782006000400048

Martins TF, Dantas-Torres F, Nieri-Bastos FA, Marcili A, Siqueira DB, Aléssio FM, Mauffrey J, Marvulo MFV, Silva JCR, Labruna MB (2009) Host records for the immature stages of the South American tick, Amblyomma fuscum (Acari: Ixodidae). Entomol News 120: 370-374. https://doi.org/10.3157/021.120.0404

Massini PF, Drozino RN, Otomura FH, Mongruel ACB, Valente JDM, Toledo MJO, Martins TF, Vidotto O, Vieira TSWJ, Vieira RFC (2019) Detection of hemotropic Mycoplasma sp. in white-eared opossums (Didelphis albiventris) from southern Brazil. Braz J Vet Parasitol 28:797-801. https://doi.org/10.1590/s1984-29612019058

Matias J, Garcia MV, Cunha RC, Aguirre AAR, Barros JC, Csordas BG, Andreotti R (2015) Spotted fever group Rickettsia in Amblyomma dubitatum tick from the urban area of Campo Grande, Mato Grosso do Sul, Brazil. Ticks Tick Borne Dis 6:107-110. https://doi.org/10. 1016/j.ttbdis.2014.10.001

Matsumoto K, Brouqui P, Raoult D, Parola P (2005) Experimental infection models of ticks of the Rhipicephalus sanguineus group with Rickettsia conorii. Vector-Borne Zoonotic Dis 5:363-372. https:// doi.org/10.1089/vbz.2005.5.363

Mejía Á, Matamoros G, Fontecha G, Sosa-Ochoa W (2018) Bionomic aspects of Lutzomyia evansi and Lutzomyia longipalpis, proven vectors of Leishmania infantum in an endemic area of non-ulcerative cutaneous leishmaniasis in Honduras. Parasit Vectors 11:15. https:// doi.org/10.1186/s13071-017-2605-7

Melo ALT, Alves AS, Nieri-Bastos FA, Martins TF, Witter R, Pacheco TA, Soares HS, Marcili A, Chitarra CS, Dutra V, Nakazato L, Pacheco RC, Labruna MB, Aguiar DM (2015) Rickettsia parkeri infecting free-living Amblyomma triste ticks in the Brazilian Pantanal. Ticks Tick Borne Dis 6:237-241. https://doi.org/10. 1016/j.ttbdis.2015.01.002

Melo ALT, de Aguiar DM, Spolidorio MG, Yoshinari NH, Matushima ER, Labruna MB, Horta MC (2016) Serological evidence of exposure to tick-borne agents in opossums (Didelphis spp.) in the state of São Paulo, Brazil. Braz J Vet Parasitol 25:348-352. https://doi.org/ 10.1590/s1984-29612016028

Mendoza-Roldan J, Ribeiro SR, Castilho-Onofrio V, Grazziotin FG, Rocha B, Ferreto-Fiorillo B, Pereira JS, Benelli G, Otranto D, Barros-Battesti DM (2020a) Mites and ticks of reptiles and amphibians in Brazil. Acta Tropica 208:105515

Mendoza-Roldan JA, Modry D, Otranto D (2020b) Zoonotic Parasites of Reptiles: A Crawling Threat. Trends Parasitol 36:677-687. https:// doi.org/10.1016/j.pt.2020.04.014

Mendoza-Roldan JA, Ribeiro SR, Castilho-Onofrio V, Marcili A, Simonato BB, Latrofa MS, Benelli G, Otranto D, Barros-Battesti DM (2021) Molecular detection of vector-borne agents in ectoparasites and reptiles from Brazil. Ticks Tick Borne Dis 12:101585. https://doi.org/10.1016/j.ttbdis.2020.101585

Miller CL, Kinsella JM, Garner MM, Evans S, Gullett PA, Schmidt RE (2006) Endemic infections of Parastrongylus (=Angiostrongylus) costaricensis in two species of nonhuman primates, raccoons, and an opossum From Miami, Florida. J Parasitol 92:406-408. https:// doi.org/10.1645/ge-653r.1

Modrý D, Fecková B, Putnová B, Manalo SM, Otranto D (2020) Alternative pathways in Angiostrongylus cantonensis (Metastrongyloidea: Angiostrongylidae) transmission. Parasitol 28: 1-7. https://doi.org/10.1017/S0031182020001857

Möhl K, Grosse K, Hamedy A, Wüste T, Kabelitz P, Lücker E (2009) Biology of Alaria spp. and human exposition risk to Alaria mesocercariae-a review. Parasitol Res 105:1-15. https://doi.org/10. 1007/s00436-009-1444-7

Moraes-Filho J, Costa FB, Gerardi M, Soares HS, Labruna MB (2018) Rickettsia rickettsii co-feeding transmission among Amblyomma aureolatum ticks. Emerg Infect Dis 24:2041-2048. https://doi.org/ 10.3201/eid2411.180451
Morshed MG, Scott JD, Fernando K, Beati L, Mazerolle DF, Geddes G, Durden LA (2005) Migratory songbirds disperse ticks across Canada, and first isolation of the Lyme Disease spirochete, Borrelia burgdorferi, from the avian tick, Ixodes auritulus. J Parasitol 91:780-790. https://doi.org/10.1645/ge-3437.1

Muller G, Brum JGW, Langone PQ, Michels GH, Sinkoc AL, Ruas JL, Berne MEA (2005) Didelphis albiventris Lund, 1841 parasitado por Ixodes loricatus Neumann, 1899 e Amblyomma aureolatum (Pallas, 1772) (Acari: Ixodidae) no Rio Grande do Sul. Arq Inst Biol 72: 319-324

Nava S, Venzal JM, González-Acuña D, Martins TF, Guglielmone AA (2017) Genera and Species of Ixodidae. In Nava S, Venzal JM, González-Acuña D, Martins TF, Guglielmone AA (eds) Ticks of the Southern Cone of America: Diagnosis, Distribution and Hosts with Taxonomy, Ecology and Sanitary Importance. Elsevier, pp 25267. https://doi.org/10.1016/B978-0-12-811075-1.00002-9

Noda AA, Rodríguez I, Miranda J, Contreras V, Mattar S (2016) First molecular evidence of Coxiella burnetii infecting ticks in Cuba. Ticks Tick Borne Dis 7:68-70. https://doi.org/10.1016/j.ttbdis. 2015.08.008

Oates SC, Miller MA, Hardin D, Conrad PA, Melli A, Jessup DA, Dominik C, Roug A, Tinker MT, Miller WA (2012) Prevalence, environmental loading, and molecular characterization of Cryptosporidium and Giardia isolates from domestic and wild animals along the central California coast. Appl Environ Microbiol 78: 8762-8772. https://doi.org/10.1128/AEM.02422-12

Olifiers N, Gentile R, Fiszon JT (2005) Relation between small-mammal species composition and anthropic variables in the Brazilian Atlantic Forest. Braz J Biol 65:495-501. https://doi.org/10.1590/S151969842005000300015

Oliveira HH, Gomes V, Amorim M, Gazêta GS, Serra-Freire NM, Quinelato IPF, Morelli-Amaral VF, Almeida AB, Carvalho RW, Carvalho AG (2014) Diversidade de ixodida em roedores e marsupiais capturados no Parque Estadual da Pedra Branca, Rio de Janeiro, Brasil. Arq Bras Med Vet e Zootec 66:1097-1104. https://doi.org/10.1590/1678-6532

Oliveira JCP, Reckziegel GH, Ramos CAN, Giannelli A, Alves LC, de Carvalho GA, Ramos RAN (2020) Detection of Rickettsia felis in ectoparasites collected from domestic animals. Exp Appl Acarol 81: 255-264. https://doi.org/10.1007/s10493-020-00505-2

Oliver JH, Magnarelli LA, Hutcheson HJ, Anderson JF (1999) Ticks and antibodies to Borrelia burgdorferi from mammals at Cape Hatteras, NC and Assateague Island, MD and VA. J Med Entomol 36:578587. https://doi.org/10.1093/jmedent/36.5.578

Otranto D (2018) Arthropod-borne pathogens of dogs and cats: from pathways and times of transmission to disease control. Vet Parasitol 251:68-77. https://doi.org/10.1016/j.vetpar.2017.12.021

Otranto D, Dantas-Torres F, Giannelli A, Latrofa MS, Cascio A, Cazzin S, Ravagnan S, Montarsi F, Zanzani SA, Manfredi MT, Capelli G (2014) Ticks infesting humans in Italy and associated pathogens. Parasit Vectors 7:1-9. https://doi.org/10.1186/1756-3305-7-328

Ouellette J, Apperson CS, Howard P, Evans TL, Levine JF (1997) Tickraccoon associations and the potential for Lyme disease spirochete transmission in the coastal plain of North Carolina. J Wildl Dis 33: 28-39. https://doi.org/10.7589/0090-3558-33.1.28

Pampiglione S, Fioravanti ML, Gustinelli A, Onore G, Mantovani B, Luchetti A, Trentini M (2009) Sand flea (Tunga spp.) infections in humans and domestic animals: state of the art. Med Vet Entomol 23: 172-186. https://doi.org/10.1111/j.1365-2915.2009.00807.x

Panti-May JA, Torres-Castro M, Hernández-Betancourt S, Dzul-Rosado K, Zavala-Castro J, López-Avila K, Tello-Martín R (2015) Detection of Rickettsia felis in Wild Mammals from Three Municipalities in Yucatan, Mexico. EcoHealth 12:523-527. https://doi.org/10.1007/s10393-014-1003-2

Parada-López J, Hernández-Betancourt SF, Ruiz-Piña HA, EscobedoOrtegón FJ, Medina-Peralta S, Panti-May JA (2013) Trypanosoma 
cruzi infection in Didelphis virginiana in relation to population parameters and variables associated with presence in rural community dwellings in Yucatan, Mexico. Ecohealth 10:31-35. https://doi.org/ 10.1007/s10393-013-0819-5

Pechous RD, Sivaraman V, Stasulli NM, Goldman WE (2016) Pneumonic Plague: the darker side of Yersinia pestis. Trends Microbiol 24:190-197. https://doi.org/10.1016/j.tim.2015.11.008

Pena HFJ, Marvulo MFV, Horta MC, Silva MA, Silva JCR, Siqueira DB, Lima PACP, Vitaliano SN, Gennari SM (2011) Isolation and genetic characterisation of Toxoplasma gondii from a red-handed howler monkey (Alouatta belzebul), a jaguarundi (Puma yagouaroundi), and a black-eared opossum (Didelphis aurita) from Brazil. Vet Parasitol 175:377-381. https://doi.org/10.1016/j.vetpar.2010.10. 015

Peniche-Lara G, Dzul-Rosado K, Pérez-Osorio C, Zavala-Castro J (2015) Rickettsia typhi in rodents and $R$. felis in fleas in Yucatán as a possible causal agent of undefined febrile cases. Rev Inst Med Trop Sao Paulo 57:129-132. https://doi.org/10.1590/s003646652015000200005

Pereira HM, Leadley PW, Proença V, Alkemade R, Scharlemann JPW, Fernandez-Manjarrés JF, Araújo MB, Balvanera P, Biggs R, Cheung WWL, Chini L, Cooper HD, Gilman EL, Guénette S, Hurtt GC, Huntington HP, Mace GM, Oberdorff T, Revenga C, Rodrigues P, Scholes RJ, Sumaila UR, Matt W (2010) Scenarios for global biodiversity in the 21st century. Science 330(80):14961501. https://doi.org/10.1126/science.1196624

Pérez-Hernandez R, Lew D, Solari S (2016) Didelphis virginiana. The IUCN Red List of Threatened Species 2016: e.T40502A22176259. https://doi.org/10.2305/IUCN.UK.2016-1.RLTS. T40502A22176259.en

Pinto IS, Botelho JR, Costa LP, Leite YLR, Linardi PM (2009) Siphonaptera associated with wild mammals from the Central Atlantic Forest biodiversity corridor in Southeastern Brazil. J Med Entomol 46:1146-1151. https://doi.org/10.1603/033.046.0523

Pinto HA, Mati VLT, de Melo AL (2014) Toxocara cati (Nematoda: Ascarididae) em Didelphis albiventris (Marsupialia: Didelphidae) do Brasil: um caso de pseudoparasitismo. Braz J Vet Parasitol 23: 522-525. https://doi.org/10.1590/S1984-29612014074

Polo G, Mera Acosta C, Labruna MB, Ferreira F (2017) Transmission dynamics and control of Rickettsia rickettsii in populations of Hydrochoerus hydrochaeris and Amblyomma sculptum. PLoS Negl Trop Dis 11:1-12. https://doi.org/10.1371/journal.pntd. 0005613

Pung OJ, Durden LA, Banks CW, Jones DN (1994) Ectoparasites of opossums and raccoons in southeastern Georgia. J Med Entomol 31:915-919. https://doi.org/10.1093/jmedent/31.6.915

Quintal APN, Ribeiro ÉS, Rodrigues FP, Rocha FS, Floeter-Winter LM, Nunes CM (2011) Leishmania spp. in Didelphis albiventris and Micoureus paraguayanus (Didelphimorphia: Didelphidae) of Brazil. Vet Parasitol 176:112-119. https://doi.org/10.1016/j.vetpar. 2010.11.011

Rands MRW, Adams WM, Bennun L, Butchart SHM, Clements A, Coomes D, Entwistle A, Hodge I, Kapos V, Scharlemann JPW, Sutherland WJ, Vira B (2010) Biodiversity conservation: challenges beyond 2010. Science 329(80):1298-1303. https://doi.org/10.1126/ science. 1189138

Rangel CH, Neiva CHMB (2013) Predação de vertebrados por cães Canis lupus familiaris (Mammalia: Carnivora) no Jardim Botânico do Rio de Janeiro, RJ, Brasil. Biodiversidade Bras 3:261-269

Ratovonjato J, Rajerison M, Rahelinirina S, Boyer S (2014) Yersinia pestis in Pulex irritans fleas during plague outbreak, Madagascar. Emerg Infect Dis 20:1414-1415. https://doi.org/10.3201/eid2008. 130629

Reck J, Souza U, Souza G, Kieling E, Dall'Agnol B, Webster A, Michel T, Doyle R, Martins TF, Labruna MB, Marks F, Ott R, Martins JR (2018) Records of ticks on humans in Rio Grande do Sul state,
Brazil. Ticks Tick Borne Dis 9:1296-1301. https://doi.org/10. 1016/j.ttbdis.2018.05.010

Reeves WK, Rogers TE, Durden LA, Dasch GA (2007) Association of Bartonella with the fleas (Siphonaptera) of rodents and bats using molecular techniques. J Vector Ecol 32:118-122. https://doi.org/10. 3376/1081-1710(2007)32[118:aobwtf]2.0.co;2

Rodríguez-Vivas RI, Apanaskevich DA, Ojeda-Chi MM, TrinidadMartínez I, Reyes-Novelo E, Esteve-Gassent MD, Pérez de León AA (2016) Ticks collected from humans, domestic animals, and wildlife in Yucatan, Mexico. Vet Parasitol 215:106-113. https:// doi.org/10.1016/j.vetpar.2015.11.010

Rojero-Vázquez E, Gordillo-Pérez G, Weber M (2017) Infection of Anaplasma phagocytophilum and Ehrlichia spp. in opossums and dogs in Campeche, Mexico: The role of tick infestation. Front Ecol Evol 5:1-9. https://doi.org/10.3389/fevo.2017.00161

Rossano MG, Kaneene JB, Marteniuk JV, Banks BD, Schott HC, Mansfield LS (2003) A herd-level analysis of risk factors for antibodies to Sarcocystis neurona in Michigan equids. Prev Vet Med 57:7-13. https://doi.org/10.1016/S0167-5877(02)00192-7

Ruiz-Piña HA, Cruz-Reyes A (2002) The opossum Didelphis virginiana as a synanthropic reservoir of Trypanosoma cruzi in Dzidzilché, Yucatán, México. Mem Inst Oswaldo Cruz 97:613-620. https:// doi.org/10.1590/S0074-02762002000500003

Sá ÉFGG, Rodrigues VDS, Garcia MV, Zimmermann NP, Ramos VN, Blecha IMZ, Duarte PO, Martins TF, Bordignon MO, Andreotti R (2018) Ticks on Didelphis albiventris from a Cerrado area in the Midwestern Brazil. Syst Appl Acarol 23:935-945. https://doi.org/ 10.11158/saa.23.5.11

Sahinduran S (2012) Protozoan diseases in farm ruminants. A Bird's-Eye View of Veterinary Medicine, In

Sakai RK, Costa FB, Ueno TEH, Ramirez DG, Soares JF, Fonseca AH, Labruna MB, Barros-Battesti DM (2014) Experimental infection with Rickettsia rickettsii in an Amblyomma dubitatum tick colony, naturally infected by Rickettsia bellii. Ticks Tick Borne Dis 5:917923. https://doi.org/10.1016/j.ttbdis.2014.07.003

Salvador CH, Carvalho-Pinto C, Carvalho R, Graipel ME, Simões-lopes PC (2007) Interação parasito-hospedeiro entre ectoparasitos (Ixodida \& Siphonaptera) e gambás Didelphis aurita WiedNeuwied, 1826 (Mammalia: Didelphimorphia), no continente e em ilhas do litoral de Santa Catarina, Sul do Brasil. Biotemas 20:81-90

Sangenis LHC, Saraiva RM, Georg I, de Castro L, Lima VS, Roque ALR, Xavier SCC, Santos LC, Fernandes FA, Sarquis O, Lima MM, Carvalho-Costa FA, Bóia MN (2015) Autochthonous transmission of Chagas disease in Rio de Janeiro State, Brazil: A clinical and ecoepidemiological study. BMC Infect Dis 15:1-12. https://oi.org/10. 1186/s12879-014-0732-8

Sangenis LHC, Nielebock MAP, da Silva SC, da Silva MCC, Bento GMR (2016) Transmissão da doença de Chagas por consumo de carne de caça: Revisão sistemática. Rev Bras Epidemiol 19:803811. https://doi.org/10.1590/1980-5497201600040010

Santana RAG, Guerra MGVB, Sousa DR, Couceiro K, Ortiz JV, Oliveira M, Ferreira LS, Souza KR, Tavares IC, Morais RF, Silva GAV, Melo GC, Vergel GM, Albuquerque BC, Arcanjo ARL, Monteiro WM, Ferreira JMBB, Lacerda MVG (2019) Oral Transmission of Trypanosoma cruzi, Brazilian Amazon. Emerg Infect Dis 25:132135. https://doi.org/10.3201/eid2501.180646

Santiago MEB, Vasconcelos RO, Fattori KR, Munari DP, Michelin AF, Lima VMF (2007) An investigation of Leishmania spp. in Didelphis spp. from urban and peri-urban areas in Bauru (São Paulo, Brazil). Vet Parasitol 150:283-290. https://doi.org/10.1016/j.vetpar.2007. 09.026

Saracho-Bottero MN, Tarragona EL, Sebastian PS, Venzal JM, Mangold AJ, Guglielmone AA, Nava S (2018) Ticks infesting cattle and humans in the Yungas Biogeographic Province of Argentina, with notes on the presence of tick-borne bacteria. Exp Appl Acarol 74: 107-116. https://doi.org/10.1007/s10493-018-0208-4 
Saraiva D, da Silva Rocha Fournier G, Pimenta de Oliveira S, Ogrzewalska M, Valadares Calaca Camara EM, Guimaraes Costa C, Botelho JR (2012) Ectoparasites from small mammals from the Cerrado region in the Minas Gerais state, Brazil. UNED Research Journal 4:21-29

Saraiva DG, Fournier GFSR, Martins TF, Leal KPG, Vieira FN, Câmara EMVC, Costa CG, Onofrio VC, Barros-Battesti DM, Guglielmone AA, Labruna MB (2012) Ticks (Acari: Ixodidae) associated with small terrestrial mammals in the state of Minas Gerais, southeastern Brazil. Exp Appl Acarol 58:159-166. https://doi.org/10.1007/ s10493-012-9570-9

Schallig HDFH, da Silva ES, Van Der Meide WF, Schoone GJ, Gontijo CMF (2007) Didelphis marsupialis (Common Opossum): A potential reservoir host for zoonotic leishmaniasis in the metropolitan region of Belo Horizonte (Minas Gerais, Brazil). Vector-Borne Zoonotic Dis 7:387-393. https://doi.org/10.1089/vbz.2006.0651

Schweigmann NJ, Pietrokovsky S, Bottazzi V, Conti O, WisniveskyColli C (1995) Interaction between Didelphis albiventris and Triatoma infestans in relation to Trypanosoma cruzi transmission. Mem Inst Oswaldo Cruz 90:679-682. https://doi.org/10.1590/ S0074-02761995000600003

Scott JD, Clark KL, Coble NM, Ballantyne TR (2019) Detection and transstadial passage of Babesia species and Borrelia burgdorferi sensu lato in ticks collected from avian and mammalian hosts in Canada. Healthcare 7:155. https://doi.org/10.3390/ healthcare 7040155

Sherlock IA (1996) Ecological Interactions of Visceral Leishmaniasis in the State of Bahia, Brazil. Mem Inst Oswaldo Cruz 91:671-683. https://doi.org/10.1590/S0074-02761996000600003

Shoop WL, Corkum KC (1981) Epidemiology of Alaria marcianae mesocercariae in Louisiana. J Parasitol 67:928-931. https://doi. org/10.2307/3280722

Silva EM, Alves LC, Guerra NR, Farias MPO, Oliveira ELR, de Souza RC, da Cunha C, Ramos RAN, Porto WJN (2016) Leishmania spp. in Didelphis spp. from Northeastern Brazil. J Zoo Wildl Med 47: 942-944. https://doi.org/10.1638/2015-0148.1

Soares HS, Barbieri ARM, Martins TF, Minervino AHH, de Lima JTR, Marcili A, Gennari SM, Labruna MB (2015) Ticks and rickettsial infection in the wildlife of two regions of the Brazilian Amazon. Exp Appl Acarol 65:125-140. https://doi.org/10.1007/s10493-0149851-6

Sorvillo FJ, Gondo B, Emmons R, Ryan P, Waterman SH, Tilzer A, Andersen EM, Murray RA, Barr R (1993) A suburban focus of endemic typhus in Los Angeles County: association with seropositive domestic cats and opossums. Am J Trop Med Hyg 48:269-273. https://doi.org/10.4269/ajtmh.1993.48.269

Souza U, Dall'Agnol B, Michel T, Webster A, Weck B, Doyle R, Kasper CB, Soares J, Martins JR, Trigo TC, Ott R, Jardim MMA, Reck J (2018) Molecular survey of Rickettsia spp. in the Neotropical deer tick Haemaphysalis juxtakochi from Brazilian Pampa. Parasitol Res 117:3293-3298. https://doi.org/10.1007/s00436-018-5996-2

Spiegel CN, Dias DBS, Araki AS, Hamilton JGC, Brazil RP, Jones TM (2016) The Lutzomyia longipalpis complex: a brief natural history of aggregation-sex pheromone communication. Parasit Vectors 9:115. https://doi.org/10.1186/s13071-016-1866-x

Sponchiado J, Melo GL, Martins TF, Krawczak FS, Labruna MB, Cáceres NC (2015) Association patterns of ticks (Acari: Ixodida: Ixodidae, argasidae) of small mammals in cerrado fragments, western Brazil. Exp Appl Acarol 65:389-401. https://doi.org/10.1007/ s10493-014-9877-9

Stanley HM, Ford SL, Snellgrove AN, Hartzer K, Smith EB, Krapiunaya I, Levin ML (2020) The Ability of the Invasive Asian Longhorned Tick Haemaphysalis longicornis (Acari: Ixodidae) to Acquire and Transmit Rickettsia rickettsii (Rickettsiales: Rickettsiaceae), the Agent of Rocky Mountain Spotted Fever, Under Laboratory
Conditions. J Med Entomol 57:1635-1639. https://doi.org/10. 1093/jme/tjaa076

Steiert JG, Gilfoy F (2002) Infection Rates of Amblyomma americanum and Dermacentor variabilis by Ehrlichia chaffeensis and Ehrlichia ewingii in Southwest Missouri. Vector-Borne Zoonotic Dis 2:5360. https://doi.org/10.1089/153036602321131841

Steindel M, Scholz AF, Toma HK, Schlemper BR Jr (1988) Presence of Trypanosoma cruzi in the anal glands of naturally infected opossum (Didelphis marsupialis) in the state of Santa Catarina, Brazil. Mem Inst Oswaldo Cruz 83:135-137. https://doi.org/10.1590/S007402761988000100017

Stone WB, Okoniewski JC, Stedelin JR (2000) Poisoning of wildlife with anticoagulant rodenticides in New York. J Wildl Rehabil 23:13-17

Stromdahl EY, Jiang J, Vince M, Richards AL (2011) Infrequency of Rickettsia rickettsii in Dermacentor variabilis removed from humans, with comments on the role of other human-biting ticks associated with spotted fever group rickettsiae in the United States. Vector-Borne Zoonotic Dis 11:969-977. https://doi.org/10.1089/ vbz.2010.0099

Suzán G, Ceballos G (2005) The role of feral mammals on wildlife infectious disease prevalence in two nature reserves within Mexico City limits. J Zoo Wildl Med 36:479-484. https://doi.org/10.1638/ 04-078.1

Szabó MPJ, Labruna MB, Castagnolli KC, Garcia MV, Pinter A, Veronez VA, Magalhães GM, Castro MB, Vogliotti A (2006) Ticks (Acari: Ixodidae) parasitizing humans in an Atlantic rainforest reserve of Southeastern Brazil with notes on host suitability. Exp Appl Acarol 39:339-346. https://doi.org/10.1007/s10493-0069013-6

Szabó MPJ, Nieri-Bastos FA, Spolidorio MG, Martins TF, Barbieri AM, Labruna MB (2013) In vitro isolation from Amblyomma ovale (Acari: Ixodidae) and ecological aspects of the Atlantic rainforest Rickettsia, the causative agent of a novel spotted fever rickettsiosis in Brazil. Parasitol 140:719-728. https://doi.org/10.1017/ S0031182012002065

Szabó MPJ, Martins TF, Barbieri ARM, Costa FB, Soares HS, TolesanoPascoli GV, Torga K, Saraiva DG, Ramos VN, Osava CF, de Castro MB, Labruna MB (2020) Ticks biting humans in the Brazilian savannah: attachment sites and exposure risk in relation to species, life stage and season. Ticks Tick Borne Dis 11:101328. https://doi.org/ 10.1016/j.ttbdis.2019.101328

Tarragona EL, Mastropaolo M, Zurvera D, Beldomenico PM, Guglielmone AA (2018) Host-parasite association between Didelphis albiventris (Didelphimorphia: Didelphidae) and Ixodes loricatus (Acari: Ixodidae) in their southern ranges. Exp Appl Acarol 75:129-134. https://doi.org/10.1007/s10493-018-0248-9

Tenório MS, Oliveira e Sousa L, Alves-Martin MF, Paixão MS, Rodrigues MV, Starke-Buzetti WA, Araújo Junior JP, Lucheis SB (2014) Molecular identification of trypanosomatids in wild animals. Vet Parasitol 203:203-206. https://doi.org/10.1016/j.vetpar.2014. 02.010

Teodoro AKM, Cutolo AA, Motoie G, Meira-Strejevitch CS, PereiraChioccola VL, Mendes TMF, Allegretti SM (2019) Gastrointestinal, skin and blood parasites in Didelphis spp. from urban and sylvatic areas in São Paulo state, Brazil. Vet Parasitol Reg Stud Reports 16:100286. https://doi.org/10.1016/j.vprsr.2019. 100286

Torres-Castro M, Noh-Pech H, Puerto-Hernández R, Reyes-Hernández B, Panti-May A, Hernández-Betancourt S, Yeh-Gorocica A, González-Herrera L, Zavala-Castro J, Puerto FI (2016) First molecular evidence of Toxoplasma gondii in opossums (Didelphis virginiana) from Yucatan, Mexico. Open Vet J 6:57-61. https:// doi.org/10.4314/ovj.v6i1.8

Torres-Montoya EH, Zazueta-Moreno JM, Osuna-Martínez LU, CastilloUreta H, Silva-Hidalgo G, López-Moreno HS, Osuna-Ramírez I, Noguera-Corona E, Rendón-Maldonado JG (2018) 
Histopathological changes in the liver and stomach of Didelphis virginiana (Didelphimorphia: Didelphidae) during natural infection with Gnathostoma turgidum (Nematoda: Gnathostomidae). J Helminthol 92:765-768. https://doi.org/10.1017/ S0022149X17000980

Travi BL, Jaramillo C, Montoya J, Segura I, Zea A, Gonçalves A, Velez ID (1994) Didelphjs marsupialis, an important reservoir of Trypanosoma (Schizotrypanum) cruzi and Leishmania (Leishmania) chagasi in Colombia. Am J Trop Med Hyg 50:557565. https://doi.org/10.4269/ajtmh.1994.50.557

Travi BL, Osorio Y, Guarín N, Cadena H (1998) Leishmania (Leishmania) chagasi: Clinical and Parasitological Observations in Experimentally Infected Didelphis marsupialis, Reservoir of New World Visceral Leishmaniasis. Exp Parasitol 88:73-75. https://doi. org/10.1006/expr.1998.4214

Tufts DM, Goodman LB, Benedict MC, Davis AD, VanAcker MC, Diuk-Wasser M (2020) Association of the invasive Haemaphysalis longicornis tick with vertebrate hosts, other native tick vectors, and tick-borne pathogens in New York City. USA. Int J Parasitol In Press. https://doi.org/10.1016/j.ijpara.2020.08.008

Urdaneta-Morales S, Nironi I (1996) Trypanosoma cruzi in the anal glands of urban opossums. I - Isolation and experimental infections. Mem Inst Oswaldo Cruz 91:399-403. https://doi.org/10.1590/ S0074-02761996000400002

Urdapilleta M, Linardi PM, Lareschi M (2019) Fleas associated with sigmodontine rodents and marsupials from the Paranaense Forest in Northeastern Argentina. Acta Trop 193:71-77. https://doi.org/ 10.1016/j.actatropica.2019.02.011

Voss RS, Jansa SA (2009) Phylogenetic relationships and classification of didelphid marsupials, an extant radiation of New World metatherian mammals. Bull Amer Mus Nat Hist 322. http://hdl. handle.net/2246/5975

Voss RS, Jansa SA (2012) Snake-venom resistance as a mammalian trophic adaptation: lessons from didelphid marsupials. Biol Rev 87:822-837. https://doi.org/10.1111/j.1469-185X.2012.00222.x

Wang QP, Lai DH, Zhu XQ, Chen XG, Lun ZR (2008) Human angiostrongyliasis. Lancet Infect Dis 8:621-630. https://doi.org/10. 1016/S1473-3099(08)70229-9

White SA, Bevins SN, Ruder MG, Shaw D, Vigil SL, Randall A, Deliberto TJ, Dominguez K, Thompson AT, Mertins JW, Alfred JT, Yabsley MJ (2020) Surveys for ticks on wildlife hosts and in the environment at Asian longhorned tick (Haemaphysalis longicornis)-positive sites in Virginia and New Jersey, 2018. Transbound Emerg Dis. https://doi.org/10.1111/tbed.13722

Whitten T, Demontigny C, Bjork J, Foss M, Peterson M, Scheftel J, Neitzel D, Sullivan M, Smith K (2019) Prevalence of Francisella tularensis in Dermacentor variabilis ticks, Minnesota, 2017. Vector-Borne Zoonotic Dis 19:596-603. https://doi.org/10.1089/ vbz.2018.2388
Wikswo ME, Hu R, Metzger ME, Eremeeva ME (2007) Detection of Rickettsia rickettsii and Bartonella henselae in Rhipicephalus sanguineus ticks from California. J Med Entomol 44:158-162. https://doi.org/10.1093/jmedent/41.5.158

Williams SG, Sacci JB, Schriefer ME, Andersen EM, Fujioka KK, Sorvillo FJ, Barr AR, Azad AF (1992) Typhus and typhuslike rickettsiae associated with opossums and their fleas in Los Angeles County, California. J Clin Microbiol 30:1758-1762. https://doi. org/10.1128/jcm.30.7.1758-1762.1992

Witter R, Martins TF, Campos AK, Melo AL, Corrêa SH, Morgado TO, Wolf RW, May-Júnior JA, Sinkoc AL, Strüssmann C, Aguiar DM, Rossi RV, Semedo TB, Campos Z, Desbiez AL, Labruna MB, Pacheco RC (2016) Rickettsial infection in ticks (Acari: Ixodidae) of wild animals in midwestern Brazil. Ticks Tick Borne Dis 7:415423. https://doi.org/10.1016/j.ttbdis.2015.12.019

Xu G, Pearson P, Dykstra E, Andrews ES, Rich SM (2019) Human-biting Ixodes ticks and pathogen prevalence from California, Oregon, and Washington. Vector-Borne Zoonotic Dis 19:106-114. https://doi. org/10.1089/vbz.2018.2323

Yai LE, Cañon-Franco WA, Geraldi VC, Summa ME, Camargo MC, Dubey JP, Gennari SM (2003) Seroprevalence of Neospora caninum and Toxoplasma gondii Antibodies in the South American Opossum (Didelphis marsupialis) From the City of São Paulo, Brazil. J Parasitol 89:870-871. https://doi.org/10.1645/GE83R

Youssefi MR, Rahimi MT (2014) Extreme human annoyance caused by Ctenocephalides felis felis (cat flea). Asian Pac J Trop Biomed 4: 334-336. https://doi.org/10.12980/APJTB.4.2014C795

Zanette RA, da Silva AS, Lunardi F, Santurio JM, Monteiro SG (2008) Occurrence of gastrointestinal protozoa in Didelphis albiventris (opossum) in the central region of Rio Grande do Sul state. Parasitol Int 57:217-218. https://doi.org/10.1016/j.parint.2007.10. 001

Zecca IB, Hodo CL, Slack S, Auckland L, Hamer SA (2020) Trypanosoma cruzi infections and associated pathology in urbandwelling Virginia opossums (Didelphis virginiana). Int. J Parasitol Parasites Wildl 11:287-293. https://doi.org/10.1016/j.ijppaw.2020. 03.004

Zeringóta V, Maturano R, Luz HR, Senra TOS, Daemon E, Faccini JLH, McIntosh D (2017) Molecular detection of Rickettsia rhipicephali and other spotted fever group Rickettsia species in Amblyomma ticks infesting wild birds in the state of Minas Gerais, Brazil. Ticks Tick Borne Dis 8:81-89. https://doi.org/10.1016/j.ttbdis.2016.10.001

Publisher's note Springer Nature remains neutral with regard to jurisdictional claims in published maps and institutional affiliations. 